\title{
ON BEING OVERLY DISCRETE AND INSULAR: INVOLUNTARY GROUPS AND THE ANGLO-AMERICAN JUDICIAL TRADITION
}

\author{
By Aviam Soifer*
}

\begin{abstract}
"This history goes forward and goes backward, as occasion calls. Nimble center, circumference elastic you must have."

Herman Melville ${ }^{1}$

" ' $[$ C $]$ ollectively' . . is the smudgiest word in the English language."

Frederic Maitland ${ }^{2}$
\end{abstract}

History is crucial in identifying groups that warrant particular legal protection. ${ }^{3}$ Yet it is common to try to cut off the past so that the future can be approached with unbounded optimism. People in the United States are particularly notorious for assuming that the past has

* Professsor of Law, Boston University. The author is particularly grateful to Yoram Dinstein, Leon Sheleff, and the other participants in the Minority Rights Conference; to Milner Ball and the participants in the University of Georgia faculty workshop, who heard and helped with an early version; to Kathryn Abrams, Mary Ann Glendon, Arnon Gutfeld, Haggai Hurvitz, Natan Lerner, John Leubsdorf, Kenneth Mann, Martha Minow, and David Seipp for their friendship and assistance with this essay; and to the law library staffs at Boston University and Tel Aviv University for their kindness and tenacity.

1 H. Melville, Pierre or, The Ambiguities Ch.8 (1852).

2 F. W. Maitland, "Moral Personality and Legal Personality", Sidgwick Lecture at Newnham College (1903), reprinted in Maitland: Selected Essays 222, 236 (H. D. Hazeltine et al., eds., 1936).

3 The first broad elaboration of specific protection for the rights of minorities as minorities occurred in treaties, international law instruments, and court opinions following World War I. For recent discussion underscoring the importance of history and tradition in definitions of group rights in international law, see $\mathrm{N}$. Lerner, Group Rights and Discrimination in International Law Ch. 2 (forthcoming, 1990); Y. Dinstein, "Discrimination and International Human Rights", 15 Israel Yearbook on Human Rights 11 (1985); Y. Dinstein, "Collective Human Rights of Peoples and Minorities”, 25 Int'l \& Comp. L. Q. 102 (1976) [hereinafter: "Collective Human Rights"]. For specific background, see also essays in J. Crawford ed., Rights of Peoples (1988) and Y. Dinstein, "Human Rights: The Quest for Concretization", 1 Israel Yearbook on Human Rights 1328 , at 20 (1971). 
emphatically passed, that the past is not prologue. Still, it is worthy of notice when a majority of the Justices of the United States Supreme Court seem willfully blind to the burdens of the past. This essay sketches the profoundly ahistorical approach of judges today to precisely those groups who most obviously warrant special judicial concern if there is to be any special judicial solicitude on the basis of past wrongs.

There have been times, such as during the civil rights struggles of the 1870 s and the 1960 s, when minority groups attempted to force the United States and its courts to deliver on glittering historical promises. This essay describes judges who starkly choose the patina of neutrality over the demands of equality. Today, leading judges opt for a static, abstract ideal over what is complex, contextual, and more real historically.

The pleasant judicial assumption that all citizens of the United States have reached parity now extends even to racial matters. Garbed in purported neutrality, a majority of the Justices has gone so far as to suggest that the Federal Constitution, and their judicial oaths, actually compel them to reject special solicitude for dispossessed and victimized groups. It is striking that when English judges struggle to define the rights of minority groups, they also display a propensity to ignore discomforting history. All these Anglo-American judges appear unaware of the contemporary struggles of their transatlantic counterparts - to say nothing of their neighbours, other countries, and international legal instruments - to define and protect minority rights.

This essay's criticism of judicial ahistoricism differs from the relatively commonplace critique of "law office history", though surely there is validity to that criticism as well. ${ }^{4}$ Moreover, this essay argues neither that what has come before should automatically continue, ${ }^{5}$ nor that the past reveals a line of clear, inescapable development. In discussing legal claims rooted in the special histories and perspectives of members of discrete and insular minorities, no claim is made that such claims should always prevail. But memory does reveal past burdens, as well as the richness of resources available to deal with our troublesome heritage. The diverse backgrounds of the groups with which we define ourselves and are defined help constitute the context a judge ought to

$4 \quad$ See, e.g., C. Miller, The Supreme Court and the Uses of History (1969); "Symposium: Courts and History", 24 Cal. W. L. Rev. 227 (1988); A. H. Kelly, "Clio and the Court: An Illicit Love Affair", 1965 Sup. Ct. Rev. 119.

5 Bowers v. Hardwick, 478 U.S. 186 (1986) (assumption of ancient roots for laws proscribing homosexuality used to justify ban on consensual adult sodomy). 
consider even when - perhaps particularly when - legal arguments challenge complacent faith in the sweeping generalities of the legal status quo.

\section{DEFINING SPECIAL GROUPS: HISTORY AND INVOLUNTARY ASSOCIATION}

This essay discusses important judicial decisions about basic social units. It wrestles with legal claims that involve the definition of families, tribes, and racial, ethnic, national and religious groups. In combination but also in conflict, these relationships also define who we are. Such groups often are bunched together under the rubric of "involuntary associations". ${ }^{\text {To }}$ call them "involuntary associations", however, is to lose definitional precision and to deprecate the vital, albeit varied, importance of such collectivities in constituting individual identities. Still, it seems important to distinguish these "innate", or "immutable" group characteristics from the "voluntary associations" that so concerned Frederic Maitland and other leading legal lights who debated corporate personality incessantly from the 1880 s through the $1920 \mathrm{~s}$.

Despite recent scholarly debate about freedom of association and the role of voluntary associations, an independent freedom of association right seldom is defined concretely. For a review and commentary on these topics, see, e.g., Soifer, "Toward a Generalized Notion of the Right to Form or Join an Association': An Essay For Tom Emerson", 38 Case W. L. Rev. 641 (1987-88) (arguing for an independent freedom of association right); Soifer, Sobeloff Lecture: "Freedom of Association: Indian Tribes, Workers, and Communal Ghosts", 48 Md. L. Rev. 350 (1989) (discussing recent constitutional decisions); Soifer, "Fictions We Must Feign and Maitland's Simple Truth" (draft available) (essay discussing Anglo-American debate in early twentieth century about corporate personality). In international law, despite frequent references to freedom of peaceful assembly and to freedom of association, it still seems, as it did in 1971, that these rights "have yet to attain any meaningful concretization"; Dinstein, supra note 3 , at 20.

Legal scholars have paid less attention to so-called "involuntary associations", an inartful characterization used to distinguish the groups we are born into, and which we may not be able to leave even if we wish to do so, from allegedly "voluntary associations". Kathleen Sullivan offers a lucid introduction to some basic problems posed by "intermediate groups" - those affiliations that exist somewhere between individuals and the comprehensive state - for the currently fashionable strand of "republicanism", in which she mentions the tendency to overstate the voluntary/involuntary dichotomy. K. Sullivan, "Rainbow Republicanism", 97 Yale L. J. 1713, 1714 (1988). 
Unlike "voluntary associations", moreover, relatively little scholarly attention has been paid to the problematic nature of these so-called "natural" associations. As we will see, in the hands of Anglo-American judges committed to seeing only how individuals play life's game, these fundamental social groupings have become virtual wild-cards.

Only eighteen years after the formal abolition of slavery, at the moment when Jim Crow began to dominate the South, the United States Supreme Court declared it high time that the former slave "takes the rank of mere citizen, and ceases to be the special favorite of the law". 7 Again today, and again for the sake of presumed equality, the Court cuts off consideration of past racial wrongs. The Court's own complicity in legitimating segregation has been expunged. ${ }^{8}$ Now everyone is presumed formally equal, unencumbered by the past. All groups - voluntary and involuntary, white and black, corporations and Indian tribes - compete fairly in the political marketplace. Indeed, it would violate judicial neutrality to show special concern even for a group with a long history of being victimized. Special concern, in fact, may be invalid, since it denies equality in the great race of life.

The apparently irrepressible controversy over "Who is a Jew?" vividly illustrates how distinctions purportedly based on voluntary entrance and exit are not conclusive in determining whether one is or is not a member even of an "involuntary" association. To be Jewish may mean to be part of a family, tribe, religion, race, ethnic group, nation, culture, linguistic group, minority (or perhaps all of the above and more). Moreover, what often seems largely a symbolic issue in litigation today still implicates two additional basic questions: "Who wants to know?" and "Why?" These inquiries ought to translate directly into concern for historical context. In the years immediately following the Nazi Nuremburg laws, for example, the idea of neutrality in immigration quotas to the United States - the State Department's adamant refusal to give Jews "special treatment" - serves as a horrible

7 Civil Rights Cases, 109 U.S. 3, 25 (1883) (invalidating Civil Rights Act of 1875 that prohibited racial discrimination in public accommodations).

8 Constitutional decisions legitimating the entire apparatus of racism are legion. The classic survey is L. Miller, The Petitioners: The Story of the Supreme Court of the United States and the Negro (1966). Helpful recent accounts of specific decisions that upheld, and even required segregation, as in Berea College v. Kentucky, 211 U.S. 45 (1908), include C. Lofgren, The Plessy Case: A Legal Historical Interpretation (1987); R. Kennedy, "Race Relations Law and the Tradition of Celebration: The Case of Professor Schmidt", 86 Colum. L. Rev. 1622 (1986). 
example of why context is needed in dealing with the identification of and with involuntary groups. ${ }^{9}$

We begin with a brief sketch of the origins and historical context of the idea that arose in the late 1930s that certain "discrete and insular minorities" ought to receive special judicial scrutiny. By way of contrast, decisions today suggest that in their enthusiasm for a world of free individuals without any past, judges have begun to resemble those "most unlearned of learned men" whom Maitland described as "rigorous logicians, afraid of no conclusion that was implicit in their premisses". ${ }^{10}$ The recent, extremely parsimonious United States Supreme Court approach to "natural" groupings such as family, tribe, and racial, ethnic, and national identities demonstrates that these categories are neither natural nor neutral. Judges themselves play active roles in

See, e.g., A. Morse, While Six Million Died: A Chronicle of American Apathy 128-31 (1968). With hindsight, it is eerie to read Ernest Barker's 1934 statement that: "[E]ach society is also a plurality. It is a rich web of contained groups - religious and educational, professional and occupational; some for pleasure and some for profit; some based on neighbourhood and some on some other affinity; all dyed by national colour, and yet all (or most of them) with the capacity, and the instinct, for associating themselves with similar groups in other national societies, and thus emerging into some form of international connection." E. Barker, "Introduction" to his translation of O. Gierke, Natural Law and the Theory of Society 1500 to 1800 xxiii $(1934,1958$ ed.) Cf. E. Ehrlich, Fundamental Principles of the Sociology of Law 26-38 (W. Moll trans., 1975 ed.) (contrasting languishing genetic associations - clan, family, house, community - with flourishing associations based on "conscious human activity").

For an English summary of the latest effort by the Israeli Supreme Court to come to grips with the recurrent and vexing question of "Who Is A Jew?"; see D. Landau, "The Messianic Jews", Jerusalem Post, p. 5, 3 January 1990. (This decision, Beresford v. Minister of the Interior (H.C. 265/87), rejected the purported Jewish identity, for purposes of invoking Israel's Law of Return, of a group who said they were observant Jews who also recognized the divinity of Jesus Christ. None of the Justices contested the group's historical claim that they followed the tradition of Jewish sects from the time of the Second Temple. Justice Barak argued that, "The court was concerned with the position today, and not 2,000 years ago." Apparently no one noticed irony in handing down this decision on Christmas Day, 1989). For a good survey of the Israeli Supreme Court's previous struggles with such questions, see A. Maoz, "Who is a Jew?," 35 Midstream 11 (June/July, 1989).

10 F. W. Maitland, 2 Social England 476-89 (1894), 2 Collected Papers 477-96 (1911), also available in Selected Historical Essays of F. W. Maitland 126 (H. M. Cam ed., 1957). Maitland referred to English law developing into an occult science "under the fostering care" of the Inns of Court in the late Middle Ages, when "[n]ovel principles could not be admitted until they were disguised in some antique garb." Ibid. 
establishing and legitimating criteria that define "involuntary" groups. Yet many of the most distinguished judges in the United States, and to an extent in Great Britain as well, seem blithely unaware that "no man is himself, he is the sum of his past. There is no such thing really as 'was' because the past is." 11

\section{DISCRETE AND INSULAR MINORITIES}

\section{A. Equality: "The Usual Last Resort of Constitutional Arguments"}

In his infamous opinion for a United States Supreme Court majority in Buck v. Bell, ${ }^{12}$ Justice Oliver Wendell Holmes, Jr. seized the opportunity to indulge his eugenic beliefs by upholding the sterilization of a young woman who, it was alleged, was feeble-minded. ${ }^{13}$ That holding, and the accompanying aperçu that "three generations of imbeciles are enough", ${ }^{14}$ are sufficiently appalling to merit notice. But it is Holmes's reference to equal protection as "the usual last resort of constitutional arguments" 15 that requires brief consideration here. What led Holmes to say this?

We may think of numerous overlapping answers, of course. They include Holmes's inability to resist a well-turned phrase; his love of judicial machismo, including his frequent embrace of arbitrariness; his customary desire to provoke; and his interest in denigrating what appeared to be a sympathetic claim made by Carrie Buck's lawyer. But

11 Faulkner in the University 84 (J. Blotner \& F. Gwynn eds., 1965).

12274 U.S. 200 (1927). Justice Brandeis joined the majority; only Justice Butler dissented, without opinion.

13 Carrie Buck was an 18-year-old white inmate of Virginia's Colony for Epileptics and Feeble Minded. She was already the mother of an illegitimate child when Superintendent Bell began proceedings to have her sterilized. Stephen Jay Gould discussed this case and the eugenics movement generally in The Mismeasure of Man (1981). Gould also detailed the discovery nearly 50 years later that there actually were no imbeciles in Carrie Buck's family. S.J. Gould, “Carrie Buck's Daughter", 2 Const. Commentary 331 (1985).

274 U.S. at 207. Holmes asserted that "experience has shown that heredity plays an important part in the transmission of insanity, imbecility, etc." Ibid., 206. The particular form of the greater-includes-the-lesser-power argument that Holmes favoured generally was: if "the public welfare may call upon the best citizens for their lives", it would be "strange if it could not call upon those who already sap the strength of the state for lesser sacrifices", particularly if the public wished to "prevent being swamped with incompetence" by those "manifestly unfit". Ibid., 207.

Ibid., 208. 
there is another significant reason: the forgotten, aggressive use of equal protection by the activist Supreme Court of Holmes's time.

It is relatively well-known that during the 1920 s the Court vigorously invoked the Due Process Clause of the Fourteenth Amendment to invalidate numerous state laws. Justices Holmes and Brandeis generally dissented from what they considered anti-democratic judicial intrusions against the will of popularly elected, often progressive, legislatures. ${ }^{16}$ What has not been much noticed, however, is that for many decades, and most emphatically in the 1920s when William Howard Taft was Chief Justice, the Supreme Court delighted to use Equal Protection as a weapon for similar purposes.

Truax v. Corrigan ${ }^{17}$ exemplifies the phenomenon. In 1913, the Arizona legislature passed a statute to protect labour unions. Peaceful picketing and circulation of leaflets no longer would be considered unlawful per se, although federal courts and many state courts readily enjoined such union activity. In Arizona, peaceful union activity could no longer be enjoined, unless an injunction was necessary to prevent irreparable injury. The Arizona Supreme Court upheld this new law, claiming that it was simply a change in the rules of evidence. The Arizona legislature simply eliminated a "conclusive presumption". They did not deprive employers of vested property rights. ${ }^{18}$

16 Their famous dissents are collected and discussed in many places. The best sources include F. Frankfurter, Mr. Justice Holmes and the Supreme Court (1938); S. Konefsky, The Legacy of Holmes and Brandeis (1956). But Holmes and Brandeis did not always dissent from the Court's invocations of substantive due process. For example, both joined in striking down the Kansas Industrial Court Act, which provided for mandatory arbitration in labour disputes, Charles Wolff Packing Co. v. Court of Industrial Relations, 262 U.S. 522 (1923) and Charles Wolff Packing Co. v. Court of Industrial Relations, 267 U.S. 552 (1925), as well as in the court's use of substantive due process to invalidate Oregon's attack on private schools, Pierce v. Society of Sisters, 268 U.S. 510 (1925).

$17 \quad 257$ U.S. $312(1921)$.

18 The crucial decision in the Arizona Supreme Court was Truax v. Bisbee Local No. 380, Cooks' and Waiters' Union, 171 P. 121, 125 (1918). Justice Cunningham proclaimed that Truax had no vested property right in doing his normal amount of business and that he could not get an injunction against the boycott union members urged through peaceful picketing and leafletting. Moreover, the Court held, even if the union defendants were insolvent as Truax alleged, and a damages remedy therefore was not a realistic option, "the matter of financial worth does not limit the [Arizona] constitutional right to speak, write, and publish on all subjects." Ibid., 127. In Truax v. Corrigan, 20 Ariz. 7, 176 P. 570 (1918), the Arizona Court held that its decision in Bisbee Local No. 380 did not contravene the Fourteenth Amendment to the United States Constitution. 
Chief Justice Taft held that Arizona's attempt to protect unions violated the equal protection clause of the Federal Constitution. ${ }^{19}$ The Fourteenth Amendment "was intended to secure equality of protection", Taft wrote for the majority with a Hobbesian echo, "not only for all but against all similarly situated". ${ }^{20}$ The government had an affirmative obligation to provide protection to all against all. "Indeed", Taft proclaimed, "protection is not protection" unless the state meets this equal obligation to everyone. ${ }^{21}$ In considering all participants in the marketplace to be "similarly situated", Taft followed mainstream equal protection doctrine. Judges had used the equality argument for decades

This was William Truax's second notable trip to the United States Supreme Court. In 1915, the Court upheld William Truax's standing as an employer of aliens and used his case to strike down an Arizona constitutional initiative that had required all employers of more than five workers to employ at least 80 percent "qualified electors of native-born citizens of the United States or some sub-division thereof." Truax v. Raich, 239 U.S. 33, 35 (1915). One wonders if Williams Truax had secret backing for his legal journeys from his "English Kitchen" eatery in Bisbee to Washington, D.C., but it is hardly surprising that nativism permeated the union's subsequent claim that Truax was unfair to labour. See, e.g., the pamphlet vilifying Truax in the 1916 labor dispute, reprinted in Truax v. Bisbee Local No. 380, Cooks' and Waiters' Union, 171 Pac. 121, 122 (1918). It would probably be illuminating to trace the roles of the actors in the two Truax decisions in the intervening, infamous Bisbee deportation of July, 1917, when leading citizens rounded up hundreds of miners, forced them onto boxcars at gunpoint, and shipped them to the New Mexico desert. Federal courts held that this vigilante action did not constitute a federal crime, U.S. v. Wheeler, 254 Fed. 611 (9th Cir. 1918), aff'd., 254 U.S. 281 (1920).

257 U.S. at 333. Justices Holmes, Pitney, Clarke and Brandeis dissented. Taft's view of equal protection included an affirmative obligation of the state to provide protection: "It emphasizes the additional sanctity of a right which the clause has confirmed beyond the requirement of due process." And equal protection would be denied by "immunity granted to a class, however limited, having the effect to deprive another class, however limited, of a personal or property right" just as clearly "as if the immunity were in favor of, or the deprivation of right permitted worked against, a larger class." Holmes attacked the majority for falling prey to "the dangers of a delusive exactness in the application of the Fourteenth Amendment", ibid., 342, and explained, "There is nothing that I more deprecate than the use of the Fourteenth Amendment to prevent the making of social experiments that an important part of the community desires." Ibid., 344. Brandeis's lengthy dissent offered an essay on the history of labour relations and pointed out: "It is of the nature of our law that it has not dealt with man in general, but with him in relationships." Ibid., 355.

Ibid., 333. Both the Bisbee deportations and Truax v. Corrigan contributed to the Arizona reality experienced by Chief Justice Rehnquist and Justice O'Connor - a world, as we will see, they tend to perceive as natural, neutral, and fair. 
to invalidate social and economic legislation they perceived to be "class legislation". ${ }^{22}$ It was precisely this aggressive use of equal protection that made the concept of judicial enforcement of equality a target worthy of special ridicule for Holmes. And Holmes's facile dismissal of equality claims in 1927 generally carried the day, and most of the next decade.

\section{B. 25 April 1938: A Footnote in the Sands of Time}

The Spring of 1938 undid Holmes's consignment of equality claims to the dustbin of constitutional history. The Supreme Court began to suggest a new approach to prejudice and discrimination against groups. Because of two judicial pronouncements on 25 April, 1938, probably the only more significant date in American law in this century is 17 May 1954, when the Supreme Court unanimously invalidated official segregation in public schools in Brown v. Board of Education. ${ }^{23}$ Unlike Brown, however, the judicial handiwork that day attracted virtually no public attention. ${ }^{24}$ The two key decisions involved obscure plaintiffs and seemed to decide only issues of "lawyers' law". Yet these two cases marked a watershed. A new majority of the Court struggled to reduce activism by Federal Judges on the one hand, while encouraging judicial intervention in a select category of cases on the other. The Court's approach that cloudy Spring day has dominated constitutional discourse in the United States ever since.

The first decision, Erie R. R. Co. v. Tompkins, ${ }^{25}$ need not detain us long. (It remains part of virtually every American law student's nightmarish introduction to the perplexity of trying to "think like a lawyer"

22 In Gulf, Colorado \& Sante Fe Railway v. Ellis, 165 U.S. 150, 154, 165 (1897), for example, Justice Brewer invalidated a Texas statute that allowed claimants against railroads up to $\$ 10$ in attorneys' fees, since to single out railroad corporations was to "make the protecting clauses of the Fourteenth Amendment a mere rope of sand" and to fail "the constitutional obligation of equal protection". For further examples and an insightful discussion of early equal protection doctrine, see R. Kay, "The Equal Protection Clause in the Supreme Court, 1873-1903", 29 Buffalo L. Rev. 667 (1980). Brown v. Board of Education, 347 U.S. 483 (1954).

24 I have found no contemporaneous mention at all on the Carolene Products decision in leading newspapers; there was hardly much more coverage of the Erie decision. See T. Freyer, Harmony and Dissonance: The Swift \& Erie Cases In American Federalism (1981).

25304 U.S. 64 (1938). For a useful discussion of the importance of this decision, and its historic context, see Freyer, supra, note 24. 
in the peculiar American federal judicial system. $)^{26}$ The day's other crucial judicial pronouncement suggested that the Federal Constitution might compel judges to play a special, activist role when they review discrimination against "discrete and insular minorities". Ironically, this idea appeared only in footnote four to an otherwise obscure opinion written by Justice Harlan Fiske Stone, in United States v. Carolene Products. ${ }^{27}$ Yet the approach the footnote's three paragraphs suggested was to prove crucial in the treatment of minorities in American law. ${ }^{28}$ A brief description of the footnote is necessary to understand what the Court did and did not say about special judicial scrutiny of government actions affecting certain groups. It will also illuminate the pervasive retrenchment from the footnote four approach in recent Supreme Court decisions.

\section{Carolene Products}

Actually, the Carolene Products holding was part of a trend toward a new, limited role for federal courts. In contrast to the rash of decisions

26 In Erie R. R. Co. v. Tompkins, Justice Brandeis reformulated the relationship between federal and state law and between federal and state courts. Suffice it to note that the constitutional basis of Brandeis's decision on federalism is hard to locate, but that this decision about diversity jurisdiction was the culmination of a campaign he and Holmes had orchestrated for decades to try to halt freewheeling federal court intervention against the progressive possibilities they saw in social experimentation in the individual states. On the other hand, Erie rejected the defence of the older diversity doctrine that proclaimed that outsiders needed protection from the manipulation of state law by state courts in the interests of local insiders. Erie, in this sense, refused to continue to view out-ofstate legal claimants as a group in need of special, federal court protection.

304 U.S. 144 (1938). Actually, only three Justices joined that part of Stone's opinion which contained the famous footnote: Chief Justice Charles Evans Hughes, Justice Louis D. Brandeis and Justice Owen J. Roberts. Justice Hugo L. Black refused to agree to that part of Stone's opinion, since Black wished to go further than Stone in proclaiming deference to legislative judgments. Justice Pierce Butler concurred only in the result; Justice James C. McReynolds dissented; and Justices Benjamin N. Cardozo and Stanley F. Reed did not take part.

28 Even former Justice Lewis F. Powell, who helped lead the recent retrenchment from the footnote four approach, acknowledged that this footnote contained "perhaps the most far-sighted dictum in our modern judicial heritage." L. F. Powell, "Carolene Products Revisited”, 82 Colum. L. Rev. 1087 (1982). Numerous other commentators, most notably John Hart Ely in his influential book, Democracy and Distrust (1980), have celebrated and elaborated constitutional norms as extrapolations from the famous footnote. For further discussion, see L. Lusky, "Footnote Redux: A Carolene Products Reminiscence", 82 Colum. L. Rev. 1093 (1982). 
that had invalidated important elements of the New Deal and triggered Franklin Delano Roosevelt's court-packing scheme in 1937, the new judicial outlook proclaimed extreme judicial deference to the social and economic policies of the popularly-elected branches. Justice Stone's majority opinion sought to consolidate developing restraints on judicial intervention in economic matters. ${ }^{29}$ It suggested virtually an ironclad presumption in favour of the constitutionality of all social and economic legislation, including Congress' power to regulate the quality, as well as the price of milk shipped in interstate commerce. ${ }^{30}$ In footnote four, however, Stone went on to suggest the categories of constitutional claims that might deprive government action of the extreme deference it otherwise should enjoy.

The first paragraph, added at the urging of Chief Justice Hughes, has been the least controversial. That paragraph suggested special judicial concern when rights explicit in the text of the Constitution are at issue. This individualistic, "interpretivist" position involved less of a judicial leap than the possibility, mentioned in the rest of the footnote, of additional grounds for judicial refusal to defer to judgments of other governmental branches.

The footnote's second paragraph suggested special judicial skepticism in challenges to any State action that might interfere with "those political processes which can ordinarily be expected to bring about repeal of undesirable legislation". This paragraph seems premised on the assumption of a regulated social life gradually purifying itself of undesirable legislation. To illustrate the ways in which clogged political channels might be grounds for unusually exacting judicial review, Stone cited earlier decisions invalidating restrictions on the right to vote, the

West Coast Hotel Co. v. Parrish, 300 U.S. 379 (1937) symbolized the new trend. In this decision upholding state minimum wage legislation, the Court reversed itself dramatically and abandoned the individualistic, substantive due process approach generally connected to Lochner v. New York, 198 U.S. 45 (1905) and its progeny. This change, cleverly albeit inaccurately dubbed the "switch in time that saved nine", is often invoked to describe a constitutional revolution associated with President Franklin Roosevelt's New Deal. See generally B. A. Ackerman, "Discovering the Constitution", 93 Yale L. J. 1013 (1984) (identifying selfgovernment on a national level during three "constitutional moments").

Stone's opinion upheld a 1923 federal ban on the interstate shipment of filled milk. The Court reversed a lower federal court and, indirectly, the Illinois Supreme Court. It held that Congress had power to label as adulterated "Milnut", a form of skimmed milk in which butterfat was replaced by cheaper, less wholesome coconut milk. This now seems unremarkable. At the time, however, not only was the result in Carolene Products somewhat innovative, but the theory of special judicial scrutiny in footnote four was new and even daring. 
dissemination of information, freedom of political association, and peaceable assembly. ${ }^{31}$

The footnote's third and final paragraph is the most important for our purposes. Government action directed at particular religious, national, or racial minorities, Stone said, might merit special judicial scrutiny. He summarized the problem as "prejudice against discrete and insular minorities". Such prejudice, Stone asserted in language that was notably cautious and abstract, if not obscure, "may be a special condition, which tends seriously to curtail the operation of those political processes ordinarily to be relied upon to protect minorities, and which may call for a correspondingly more searching judicial inquiry." 32

Judicial and scholarly disagreement has continued and intensified about when and if any special, activist role is appropriate for judges confronting claims by "discrete and insular" groups. ${ }^{33}$ It is useful to divide the main arguments centering on footnote four into two questions: First, if we assume that the category "discrete and insular minori-

31 All of the decisions Stone cited are at least partially First Amendment decisions, with the exception of two "right to vote" cases: Nixon v. Herndon, 273 U.S. 536 (1927) and Nixon v. Condon, 286 U.S. 73 (1932). These invalidated attempts to exclude blacks entirely from voting in Democratic Party primaries in Texas. Ironically, Herndon was written by Justice Holmes, who found it "hard to imagine a more direct and obvious infringement of the fourteenth amendment", though his vilification of equality claims in Buck $v$. Bell came less than two months later, supra note 12.

32 For this crucial proposition, Stone cited two commerce clause decisions, as well as First Amendment decisions that invalidated laws held to be discriminatory based on religion and national origin and the racial discrimination in voting cases he also cited in the previous paragraph.

The Court neither immediately nor fully adopted the activist, strict scrutiny approach suggested by footnote four. This was quickly underscored in Missouri ex rel. Gaines v. Canada, 305 U.S. 337 (1938), the Court's first great step toward Brown v. Board of Education, supra note 23. In holding that the exclusion of a black man from the University of Missouri Law School was unconstitutional, the Court made no mention of footnote four, nor did the decision reflect the footnote's proposed approach. Chief Justice Hughes's majority opinion stressed only that separate had to be equal. Therefore, Missouri's offer to pay tuition for Gaines to attend an integrated law school in a neighbouring state did not satisfy his personal right. "It was as an individual that he was entitled to the equal protection of the laws", Hughes stated, and Missouri was bound to afford him substantially equal legal education, "whether or not other negroes sought the same opportunity". 305 U.S. at 351. By 1954, however, such insistent individualism seemed to disappear as the Court proclaimed that an entire class of black students, with hearts and minds ineluctably assaulted by official segregation, could not be equal so long as the law kept them separate. 
ties" includes African-Americans, what, if any, other groups ought to be included? Second, does paragraph three of the footnote essentially overlap with the footnote's other paragraphs, or does it supplement them by suggesting additional judicial solicitude for certain groups ${ }^{34}$

"Discrete and insular minorities" seemed to designate longstanding outgroups, groups in which membership itself often became a cause for mistrust, hostility, or worse. These unmeltable groups experienced "special vulnerability to predictable perversions by the majoritarian process." 35 In other words, these minorities repeatedly have been made scapegoats. Majoritarian politics obviously long has been - and still is - manipulated through explicit or encoded racism. African-Americans seemed the paradigmatic "footnote four" minority. Past discrimination and present membership yield current injury. Moreover, this is a special injury, to which attention must be paid. The injury is uniquely prone to be exacerbated, either by invidious legislation or by the absence of legislation. This renders judicial neutrality not neutrality, but rather complicity in perpetuating past wrongs.

34 Notoriously, during World War II the Court for the first time stated explicitly that racial discrimination should trigger strict judicial scrutiny, but did so as a majority of the Justices failed to discern racial discrimination in a series of cases arising out of the internment of the Japanese-Americans living on the West Coast. The Court in Korematsu v. United States, 323 U.S. 214 (1944) found a compelling government interest sufficient to override the claims of the interned Japanese. For a lucid historical treatment of the wartime litigation, see P. Irons, Justice at War (1983), which includes discussion of the movement for reparations for historic wrongs and the launching of successful coram nobis cases brought, decades later, to vacate the sentences of Japanese-Americans convicted for curfew and internment order violations.

After the war, however, the Court refused to allow California to deny commercial fishing licenses to Japanese aliens. Takahashi v. Fish and Game Commission, 334 U.S. 410, 420 (1948) (even if legitimate state objectives were assumed, California statute that barred persons "ineligible for citizenship" - e.g., Japanese - from commercial fishing licenses held to violate federal statutory and constitutional guarantees that "protect 'all persons' against state legislation bearing unequally upon them either because of race or color".) Justice Black wrote for the majority; Justice Murphy, joined by Justice Rutledge, concurred separately, emphasizing the extent to which the 1943 California statute was a direct outgrowth of anti-Japanese antagonism; and Justice Reed dissented. Ironically, the precedent most directly relied on by both Black and Reed was Truax v. Raich, 239 U.S. 33 (1915), discussed supra, note 19. See also Oyama v. California, 332 U.S. 633, 646 (1948) (invalidating escheat to California of land held by interned Japanese alien as guardian for son because "only the most exceptional circumstances can excuse [racial] discrimination").

35 R. Cover, "The Origins of Judicial Activism in the Protection of Minorities", 91 Yale L. J. 1287, 1292 n. 14 (1982). 
Footnote four appeared the month after Hitler took over Austria, as Stalin's show trials disposed of the last of the old Bolsheviks, and as Italian and German aid decisively turned the tide to Franco in the Spanish Civil War. ${ }^{36}$ Even within the largely isolationist United States, labour battles and ethnic and racial tension added to what seemed a particularly explosive Spring. ${ }^{37}$ As Robert Cover put it, "[M]inorities ... in the sense we use the term today - religious, ethnic, national, and racial minorities - became a special object of judicial protection only with footnote four, which was written at almost the exact moment when majoritarianism became the dominant constitutional perspective." 38 The paragraph suggested the need for judicial limits on permissible democratic action, and even certain inaction, that perpetuated the burdens of past victimization of special groups.

As new groups, such as mentally retarded, physically handicapped and homosexual citizens began to allege discriminatory treatment, the meaning of "discrete and insular minorities" began to seem increasingly problematic. ${ }^{39}$ Moreover, determining what groups are "similarly situ-

36 D. Thomson, Europe Since Napoleon 711-30 (rev. ed., 1966). For a succinct description of the unexaggeratable horror of the Anschluss, which brought forms of anti-Semitism more virulent than anything yet practiced in Germany, see P. Gay, Freud: A Life for Our Time 622-28 (pap. ed. 1989) (including direct impact on aged Sigmund Freud and his family, despite personal efforts by Roosevelt and others on their behalf). N.Y. Times, 4 April 1938, p. 1, cols. 1, 2, 3.

37 In hindsight, the dramatic sit-in strikes in 1937 and the labour violence that followed suggested that "the American labor movement has been the most violent nonrevolutionary movement in the world; but the middle-class character of labor's goals could have been doubted then." J. W. Howard, Mr. Justice Murphy 157 (1968). As economic recession worsened in early 1938, the CIO formally broke away from the AFL and Congress, worried about internal threats, created the forerunner of the House Un-American Activities Committee, chaired by Representative Martin Dies. The deteriorating economic situation; vigorous, even violent, domestic conflict triggered by events in Europe, such as violence surrounding meetings of the German-American Bund in New York City; and obvious, massive cracks in the reigning Democratic Party coalition made it seem in the Spring of 1938 that the New Deal, and perhaps the nation, might be in danger of collapse.

Cover, supra note 36 , at 1294 . Cover made it clear that he referred only to American law and assigned pride of place to international law for recognizing and attempting to do something to protect minorities in the wake of World War I. Ibid., 1297.

39 M. Minow, "The Supreme Court, 1986 Term-Foreword: Justice Engendered," 101 Harv. L. Rev. 10 (1987) provides a summary of recent cases and a provocative discussion of the "difference dilemma". 
ated" - the grundnorm for assuring them legal equality - depends on where you are when you happen to look. The Court vividly illustrated this when it rejected an equal protection challenge to the denial of state disability benefits to pregnant women on the grounds that the distinction drawn by California was between "pregnant women and nonpregnant persons", rather than between women and men..$^{40}$ Despite a flood of equal protection decisions, the legal argument still focuses on whether it is appropriate to relegate those who claim discrimination at the hands of the majority to the economic or political marketplace.

A majority of the Justices today seems to share a pervasive national nostalgia for a simpler, freer, and happier time-that-never-was. Only a smoking gun - i.e., incontrovertible proof of a specific racially discriminatory motive that an individual plaintiff can tie directly to his or her own plight - will move the Court to acknowledge that discrimination, even against African-Americans, may still be legally relevant. ${ }^{41}$ Judges thus simplify their work by deferring to whatever results emerge from a Hobbesian social struggle. Even better, each citizen has only himself to blame if he loses in life's great struggle. The sobering history of different groups has been called off. The dream of equality for all individuals has been achieved. It is everyone for his future self.

\section{THE FIFTY YEAR GAP: FREEDOM FROM ASSOCIATION WITH GUILT}

\section{A. Patterson v. McLean Credit Union I: "External Criteria"}

To love history is probably to love coincidence. Fifty years to the day after Carolene Products, the United States Supreme Court announced, by a 5-4 vote, that a case involving alleged racial harassment, Patterson

40 Geduldig v. Aiello, 417 U.S. 484, 496-97 n. 20 (1974). Although the issue of gender difference is beyond the scope of this essay, issues of sameness and difference are crucial to much contemporary feminist discourse.

41 There has been considerable discussion of this trend. For criticism of its beginnings, see, e.g., Soifer, "Complacency and Constitutional Law", 41 Ohio State L.J. 383 (1981); a careful dissection of the crucial middle stage is available in K. M. Sullivan, "Sins of Discrimination: Last Term's Affirmative Action Cases", 100 Harv. L. Rev. 78 (1986); the most recent aspects were unpacked skillfully in A. Rosenfeld, "Decoding Richmond: Affirmative Action and the Elusive Meaning of Constitutional Equality," 87 Mich. L. Rev. 1729 (1989). 
v. McLean Credit Union, ${ }^{42}$ would be set down for reargument. The Court asked the lawyers to address a question not previously raised. The Justices took the initiative to ask: Should the Court overrule a 1976 decision, Runyon v. McCrary, that held that the 1866 Civil Rights Act prohibited private schools from excluding qualified children solely because of their race $?^{43}$ This question touched off a passionate public debate unusual even in a nation obsessed with what the Supreme Court seems to be doing. At the moment, however, the language used by the five Justices who voted to pose that question for reargument merits close attention. The brief per curiam opinion captures the recrudescence of an extreme, abstract individualistic ethos in American courts today.

To begin at the conclusion: the per curiam opinion ended by responding to an argument, made in both dissenting opinions, ${ }^{44}$ that the Court should be particularly loath to upset an important statutory precedent that favours civil rights plaintiffs. The majority answered:

We do not believe that the Court may recognize any such exception

485 U.S. 617 (25 April 1988). The lower court had decided that the 1866 Civil Rights Act did not protect a black plaintiff from racial harassment in the workplace. The Court's April 25th order introduced the question: "Whether or not the interpretation of 42 U.S.C. sec. 1981 adopted by this Court in Runyon v. McCrary, 427 U.S. 160 (1976), should be reconsidered?"

43 Runyon v. McCrary, 427 U.S. 160 (1976), determined by a 7-2 vote that the 1866 Civil Rights Act could reach private acts of racial discrimination. Justice Stewart's majority opinion held that a private school that advertised widely and otherwise comported itself as a business could be held liable under the statute for overt racial discrimination. In an important separate concurring opinion, however, Justice Powell emphasized the particular commercial aspects of the school at issue, and argued that the result might well be different in the case, for example, of a private tutor. Justice White, joined by then-Justice Rehnquist, dissented, arguing that Sec. 1981 dealing with contracts ought not to be read as broadly as Sec. 1982 dealing with property rights. Justices Stevens and Powell concurred separately. Both argued that they would decide otherwise if the case posed a new question, but that stare decisis required them to agree with the majority, though they cautioned against a broad reading of its holding.

Justice Blackmun, joined by Justices Brennan, Marshall, and Stevens, objected to the majority's decision to reach out "to reconsider an interpretation of a civil rights statute that so clearly reflects our society's earnest commitment to ending racial discrimination." 485 U.S., at 621 . Justice Stevens, joined by the three other dissenters, wrote a separate dissent in which he decried the majority's decision because it "replace[s] what is ideally a sense of guaranteed right with the uneasiness of unsecured privilege." Ibid., 622. Stevens also noted the deleterious impact of the decision not only on faith in law maintained by victims of discrimination, but also on public perceptions of the Court as impartial and restrained. 
to the abiding rule that it treat all litigants equally: that is, that the claim of any litigant for the application of a rule to its case should not be influenced by the Court's view of the worthiness of the litigant in terms of extralegal criteria. We think this is what Congress meant when it required each Justice or judge of the United States to swear to "administer justice without respect to persons, and do equal right to the poor and to the rich ..."45

We should attend to three distinct, although interrelated, reasons that make the majority's rhetoric in Patterson both illuminating and troubling: First, the per curiam opinion expressed the notion that race - the very criterion that constitutes the basis for civil rights claims - is fungible with other "external criteria". A higher judicial duty requires judges to treat all litigants abstractly and, thereby, to treat them formally as equal.

Second, the majority apparently believed the specific judicial obligation to do "equal right to the poor and to the rich" to be synonymous with the idea that all litigants should be treated as if they are exactly the same. The majority Justices insisted that the judicial obligation to do "equal right" requires judges to be blind to what they know as women and men. This would require judges to ignore different starting places, significant encumbrances, and the weight of the past. It rejects a basic point made by John Winthrop, Ronald Reagan's favourite Puritan, in the early days of the Massachusetts Bay Colony: "If the same penalty hits a rich man, it pains him not, it is not affliction to him, but if it lights upon a poor man, it breaks his back." 46 Yet litigants are not interchangeable ciphers. They are defined by their histories and their group associations. Thus the Court noted, as it struck down state court enforcement of restrictive covenants in 1948, "Equal protection of the laws is not achieved by indiscriminate imposition of inequalities." ${ }^{47}$

Ibid., 619, quoting 28 U.S.C. Sec. 453 (1948).

4 Winthrop Papers 349, 351-52 (Mass. Hist. Soc. 1929-1947), anticipating William Blake in "The Marriage of Heaven and Hell", stating that "One Law for the Lion \& Ox is Oppression", Poetry and Prose of William Blake 191 (G. Keynes ed. 1961). Cf. Plato, 2 The Republic VIII, Sec. 558, at 291 (P. Shorey trans., 1956 ed.) (describing democracy as "anarchic and motley, assigning a kind of equality indiscriminately to equals and unequals alike").

47 Shelley v. Kraemer, 334 U.S. 1, 22 (1948). Philip Kurland aptly termed Chief Justice Vinson's Shelley opinion "the Finnegan's Wake of constitutional law"; P. Kurland, "Foreword: Equal in Origin and Equal in Title to the Legislative and Executive Branches of the Government", 78 Harv. L. Rev. 143, 148 (1964). 
Finally, the per curiam opinion went further than allowing the "indiscriminate imposition of inequalities". It suggested that indiscriminate treatment is obligatory. Upon close reading, however, the ironclad judicial oath the majority invoked hardly draws such individual/group and legal/extralegal distinctions. The oath does not define "equal right" as lack of awareness of group differences. Nor does it hint of distinguishing intrinsic from extrinsic characteristics. Finally, the meaning of "respect to persons" is considerably more complex in terms of both etymology and history than the per curiam opinion suggested. ${ }^{48}$ The Court aggressively presumed, however, that no approach to justice would allow judges to protect the downtrodden. This willed obliviousness toward history coexists awkwardly with recent judicial activism in constructing the very categories the judges elsewhere consider immutable, natural groupings, i.e., race, tribes, and families.

\section{B. Patterson v. McLean Credit Union II: The Result}

\section{In Patterson II, the Court unanimously agreed not to overrule Runyon}

Still, some structure emerges. Vinson emphasized that "equality in the enjoyment of property rights" was "an essential pre-condition" of other basic civil rights and civil liberties "guaranteed to the individual" by the Fourteenth Amendment, 334 U.S. at 10,22 . He made this argument to counteract a defence of the restrictive covenants that claimed that because the restrictions affected white as well as black citizens, they did not deny equal protection. Shelley's emphasis on positive as well as negative aspects of equal protection may be read as a direct repudiation of the formal equality approach of Truax $v$. Corrigan, discussed supra, in text at note 18. In Hurd v. Hodge, 334 U.S. 24 (1948), the companion case that extended Shelley to federal as well as state law, it is ironic that the trial court found the petitioner to be a Negro, though "James M. Hurd maintained that he is not a Negro but a Mohawk Indian." Ibid., 27, n. 2.

By the time of Brown v. Board of Education in 1954, Shelley's insistent individualism seemed to disappear; see supra, note 33. Cf. Beauharnais v. Illinois, 343 U.S. 250, 263 (1952) (upholding Illinois' group libel statute punishing expression "directed at groups with whose position and esteem in society the affiliated individual may be inextricably involved").

48 For a cogent explanation of the origins of the oath, and a discussion of how "the exact contours of impartiality vary with customs, law, and experience", see J. Noonan, "Judicial Impartiality and The Judiciary Act of 1789", 14 Nova L. Rev. 123 (1989). The oath was a shortened version of the oath taken by judges of the British Crown, but it incorporated an addition made in Virginia by Chancellor George Wythe. Wythe derived his addition - swearing to administer justice "without respect to persons" - from translations of Old and New Testament sources that forbade a judge to become a surety, to "lift up the face" of one being judged. "[T]hat is", as Judge Noonan put it, "not to treat the rich better than the poor". Ibid., 125. See also J. Noonan, Bribes 16, 69, 428 (1984). 
v. McCrary $^{49}$ The Justices reaffirmed that Section 1981 prohibits racial discrimination in the making and enforcement of private contracts. But the Justices disagreed vehemently about the extent of that prohibition. Justice Kennedy's majority opinion held that "the right to make contracts does not extend, as a matter of either logic or semantics, to conduct by the employer after the contract relation has been established, including breach of the terms of the contract or imposition of discriminatory working conditions." 50 On this formalistic view of contract law, the Court ignored both the substance and the historical context of the 1866 Civil Rights Act, passed primarily to protect newly-freed slaves. This is bizarre against the historic backdrop. Congress premised the 1866 Civil Rights Act on its new power under the Thirteenth Amendment, declared to be ratified only the previous December. ${ }^{51}$ The newly-freed slaves hardly came to their initial oppor-

49 Patterson v. McLean Credit Union 109 S.Ct. 2363 (1989). The Justices unanimously joined Justice Kennedy's opinion on the stare decisis point, but Justice Brennan, joined by Justices Marshall, Blackmun and, in part, Justice Stevens, dissented from the racial harassment aspect of the majority's opinion. Stevens also wrote separately in dissent.

50 109 S.Ct., at 2373 . The majority's remarkably pinched lexicographic approach was evident from the start of its discussion of the statute at issue. Justice Kennedy began by quoting Section 1981, the relevant remnant of the 1866 Civil Rights Act:

"All persons within the jurisdiction of the United States shall have the same right in every state and territory to make and enforce contracts, to sue, be parties, give evidence, and to the full and equal benefit of all laws and proceedings for the security of persons and property as is enjoyed by white citizens, and shall be subject to like punishment, pains, penalties, taxes, licenses, and exactions of every kind, and to no other." (Emphasis added).

Remarkably, however, he then asserted, "The most obvious feature of the provision is the restriction of its scope to forbidding discrimination in the 'mak[ing] and enforce[ment]' of contracts alone." $109 \mathrm{S.Ct}$., at 2372. This is "the most obvious feature" only if one stops reading at the word "contracts". To read the final part of the section, underlined above, is to be forced at least to wonder at the meaning of the clear textual effort to guarantee "full" as well as "equal" benefit of "all laws and proceedings" to "all persons". Equally noteworthy is Congress's attempt to assure that no person in the nation would suffer different pain, penalty, exaction, etc., than all other fully protected citizens might suffer.

51 The majority seemed certain of the "plain and common sense meaning" of the statutory terms "make" and "enforce" and therefore did not deign to consider the debates or political context surrounding passage of the 1866 Civil Rights Act. Yet even a most conservative contemporaneous reading of the Civil War Amendments believed it obvious that their primary purpose was to afford federal protection from "discrimination against the negroes as a class". Slaughter-House 
tunities to make and enforce contracts with equal bargaining power. Lengthy congressional hearings and debates articulated concern to guarantee equality, particularly because of extensive evidence of virulent, racially-based harassments of free contractual relationships in the South.

Justice Kennedy not only failed to heed this historic context, he belittled it. Kennedy protested too much when he proclaimed, at the conclusion of his majority opinion, that the Court was not "signaling one inch of retreat from Congress's policy to forbid discrimination in the private, as well as the public, sphere." "Nevertheless", he added, "in the areas of private discrimination, to which the ordinance of the Constitution does not directly extend", the Court must play a role "limited to interpreting what Congress may do and has done." By diminishing the Amendment that abolished private slavery and involuntary servitude throughout the nation, and by somehow rendering the Amendment not a direct part of the Constitution's "ordinance" (whatever that means), the majority proclaimed not a retreat but a rout.

\section{The Inversion of Footnote Four}

This bleak view of the result in Patterson is underscored by several other civil rights decisions by the Supreme Court last Term. City of Richmond v. J.A. Croson ${ }^{52}$ is most revealing. In invalidating a minority

Cases, 83 U.S. (16 Wall.) 36, 81 (1873). Moreover, close attention to the congressional debates, President Andrew Johnson's blundering, and the highlypublicized harshness of the end of slavery suggests that racial harassment was a serious problem, clearly targeted by Congress in 1866. See generally L. Litwack, Been in the Storm So Long (1979); E. Foner, Reconstruction - America's Unfinished Revolution, 1863-1877 (1988); Soifer, "Protecting Civil Rights: A Critique of Raoul Berger's History", 54 N.Y.U. L. Rev. 651 (1979).

5257 U.S.L.W. 4132 (1989). The Justices in the majority actually were sharply splintered, but a majority endorsed Section III-B of Justice O'Connor's lead opinion, the section to be discussed briefly. Justices Marshall and Blackmun wrote searing dissents, which Justice Brennan joined. The two other most notable decisions sharply restricting civil rights claims last Term were: Wards Cove Packing Co. v. Atonio, 109 S.Ct. 2115 (1989) (civil rights plaintiff has burden of proving employer has no business reason for practice even if it has dramatic discriminatory effects) and Martin v. Wilks, 109 S.Ct. 2180 (1989) (new group of white firefighters allowed to intervene to challenge 1981 Birmingham, Alabama consent decree alleged to be reverse discrimination). Such decisions led Justice Marshall to suggest "a deliberate retrenchment of the civil rights agenda" by the Court which put the nation "back where we started" at the time of Brown v. Board of Education. L. Greenhouse, "Marshall Says Court's Rulings Imperil Rights", N.Y. Times, at 6, 9 September 1989. 
set-aside provision in the city of Richmond, Virginia, the majority noted: "The dream of a Nation of equal citizens in a society where race is irrelevant to personal opportunity and achievement would be lost in a mosaic of shifting preferences based on inherently unmeasurable claims of past wrongs." 53 To avoid mosaic law, therefore, the majority found it necessary to restrict remedial efforts by state and local entities to situations where the effects of identified discrimination within the relevant jurisdiction can be specifically demonstrated. Otherwise, "racial politics" would now prevail. ${ }^{54}$ Thus, the history of Richmond, the capital of the Confederacy and a leading site in resistance to school integration, was quarantined, then ignored.

As Justice Marshall pointed out in passionate dissent, the majority, by adopting strict scrutiny for the first time in the context of an equal protection challenge to race-conscious remedial measures, ignored the profound difference between "governmental actions that are themselves racist, and governmental actions that seek to remedy the effects of prior racism or to prevent neutral governmental activity from perpetuating the effects of such racism." 55 Moreover, the battle against racism has hardly been won, Marshall argued, and race remains constitutionally germane, "precisely because race remains dismayingly relevant in American life". 56

The central failure of the majority opinion occurred not because issues of affirmative action are easy - they are gut-wrenchingly difficult. Nor was it only that the economic interest of a white-owned contractor, curiously the only bidder for the relevant city contract, seemed a bizarre setting for agressive protection of the equal dignity and respect of the individual plaintiff. Rather, it was the Court's willingness to operate in a vacuum, to wrench Richmond and its attempt to remedy past wrongs entirely out of the specific historical

57 U.S.L.W. at 4142.

Ibid., 4143. O'Connor's fear was not accurate in terms of the actual political situation that led to Richmond's affirmative action programme; it also simply ignored Richmond's blatantly racial political history. Moreover, she stated her discovery of racial politics at the state and local level in a manner insulting to black officeholders, as Marshall forcefully pointed out. For excellent, detailed discussion of Croson and its rhetoric, see Ross, "The Richmond Narratives," 68 Tex. L. Rev. 381 (1989); Rosenfeld, supra note 41.

Marshall, dissenting, 57 U.S.L.W. at 4155 . It is not entirely clear what test the majority agreed to use in applying "strict scrutiny" to a claim of discrimination by a white contractor. Scalia expressed an even narrower idea of what might satisfy the test than the four Justices who joined in this section of O'Connor's plurality opinion. Stevens voted with them, but did not accept the "strict scrutiny" test.

Ibid., 4157. 
setting of those wrongs. To Justice Scalia, who concurred in the judgment, "The relevant proposition is not that it was blacks, or Jews, or Irish who were discriminated against, but that it was individual men and women, 'created equal', who were discriminated against." 57

In emphasizing the need for specific proof and individualism, in denigrating group identity as a relevant factor, and rushing to jettison racial history as relevant to current reality, Patterson and Croson illustrate the complete rejection of the "footnote four" approach. Indeed, Croson comes perilously close to resuscitating Truax v. Corrigan. The majority aggressively employed what it claimed were neutral equal protection principles to invalidate reform measures not to the liking of a particular majority of the Justices. Gone is concern for "discrete and insular minorities". In its place, a white-owned business now may trigger strict judicial scrutiny of a remedial government contracting scheme.

\section{INVOLUNTARY GROUPS AS JUDICIAL CONSTRUCTS}

\section{A. Tales of Origins: Families and Tribes}

Much Anglo-American law is devoted to macadamizing and pulverizing. ${ }^{58}$ Our essential perception involves individuals on one side of the scales of justice and agencies of the state on the other. The role of courts is to balance between the two. To introduce even a third component seems unacceptable: it cannot be handled neatly in the either/or world of legal winners and losers. We picture Justice blindfolded. ${ }^{59}$ If she could see, she would require powerful bifocals.

57 Ibid., 4148. Scalia conceded that "It is plainly true that in our society blacks have suffered discrimination immeasurably greater than any directed at other racial groups" (Ibid.), but he considered this group fact constitutionally irrelevant. It is particularly ironic, in light of the judicial approach in Croson, that Justice Stevens, who concurred in part and concurred in the judgment, argued that while race is not always irrelevant, "It is the judicial system, rather than the legislative process, that is best equipped to identify past wrongdoers and to fashion remedies that will create the conditions that presumably would have existed had no wrong been committed." Ibid., 4144.

"Introduction", O. Gierke, Political Theories of the Middle Ages pp. i-xiv (F. W. Maitland trans., 1900); M. Minow, Making All the Difference: Inclusion, Exclusion, and American Law (forthcoming, 1990). Cf. "To a Steam Roller," in M. Moore, Collected Poems 90 (1961) ("You crush all particles down/into close conformity, and then walk back and forth/on them.").

D. E. Curtis \& J. Resnik, "Images of Justice", 96 Yale L. J. 1727 (1987). 
The current United States Supreme Court, in decisions ranging from who may enter court to who leaves it with a death sentence, repeatedly has emphasized the need to demonstrate particularized individual harm even to initiate any civil rights claim. ${ }^{60}$ Yet, almost despite itself, the Court frequently must deal with exactly those groups that provide identities to individuals. For example, in several decisions in the 1988 Term, the Justices wrestled with the active role of law in the construction of family units. The court also confronted several cases involving Native American tribes, social groupings so anomalous that their stories generally are omitted from American constitutional law accounts. ${ }^{61}$ Attention to the deeply paradoxical approaches the Court took in decisions about families and tribes last Term illustrates the importance of thinking more clearly about involuntary groups. Conservative judges do not simply endorse even what they believe naturally exists. Moreover, categories such as birth, genetics, and ethnicity turn out to be decidedly problematic in themselves. They are now virtually wild cards in the hands of judges.

\section{B. Legal Construction of the Family}

In a decision handed down the same day as Patterson II, Justice Scalia's plurality opinion celebrated "the historic respect - indeed, sanctity would not be too strong a term - traditionally accorded to the relationships that develop within the unitary family." ${ }^{2}$ But the Court's

60 To have standing, for example, "at an irreducible minimum, Art. III requires the party who invokes the court's authority to 'show that he personally has suffered some actual or threatened injury" "; Valley Forge College v. Americans United, 454 U.S. 464, 472 (1982) (citations omitted); see also Allen v. Wright, 468 U.S. $737,753-56$ (1984). And to make out an equal protection claim of discrimination in the imposition of the death penalty, statistics will not suffice, since the condemned person "must prove that the decisionmakers in his case acted with discriminatory purpose." McCleskey v. Kemp, 481 U.S. 279, 292 (1987) (emphasis in original). But cf. United States v. Sokolow, 109 S.Ct. 1581 (1989) ("probabilistic" factors have probative value and together amount to reasonable suspicion sufficient to support Drug Enforcement Agency airport stop of suspected drug smuggler).

61 Milner Ball and Robert Williams provide powerful elaborations of the impact of the multitude of ways in which "[t] he American story of origins fundamentally excludes tribes and denies them voice". M. Ball, "Stories of Origin and Constitutional Possibilities", 87 Mich. L. Rev. 2280, 2300 (1989); R. Williams, Jr., The American Indian in Western Legal Thought: The Discourses of Conquest (1990).

Michael H. and Victoria D. v. Gerald D., 57 U.S.L.W. 4691, 4694 (15 June 1989 ). The Justices were sharply divided and unusually vitriolic, even judged by the quite embittered standards of the current Court. Justice Scalia wrote for 
proclaimed attention to "historic respect" turned out not to respect history and only to honour abstract legal categories. In Michael $H$. $v$. Gerald $D$., the Court upheld California's conclusive presumption that precluded a biological father from introducing in court blood tests that provided clear evidence of his paternity, paternity which he and the mother acknowledged, and which he now wished to establish legally. California's legislative presumption, grounded in the Common Law, was that in a marital relationship the husband must be presumed the father of any child born to the mother during the marriage. ${ }^{63}$ The Court held that this legal construct should prevail over undisputed contrary facts. It did not matter that the child in question, aged eight at the time of the decision, joined her biological father in his constitutional challenge to California's irrebuttable presumption that precluded the "real" father and daughter from continuing their relationship.

Scalia may have been unnecessarily snide when he said, "The facts of the case are, we must hope, extraordinary." 64 But his sneering turned out to be essential to the plurality's approach. "California law, like nature itself, makes no provisions for dual fatherhood", Scalia added. ${ }^{65}$ Once he could presume this dichotomy, Scalia chose law over nature without further ado. ${ }^{66}$

himself and Chief Justice Rehnquist. They were joined in all but footnote 6 by Justices O'Connor and Kennedy. Justice Stevens concurred only in the judgment; he disagreed with Scalia's position, which Stevens took to reject the possibility that a natural father could ever have a constitutionally protected interest in his relationship with a child whose mother was married and cohabiting with another man at the time of the child's conception and birth. Stevens cast his decisive vote with Scalia, however, because Stevens read California law to afford the natural father an opportunity to be heard. Justice Brennan, joined by Justices Marshall and Blackmun, dissented from what he saw as the "make-believe" atmosphere of the plurality opinion. Ibid., 4703. Justice White, joined by Brennan, also wrote a dissent.

63 The Common Law presumption could be rebutted only by proof that the husband was incapable of procreation or by his total lack of access to the wife, and the grounds for rebuttal of the presumption were strictly construed. Ibid., 4694-95.

64 Ibid., 4691.

65 Ibid., 4693.

66 Curiously, in dismissing an unusual equal protection claim raised on behalf of the daughter, Scalia explicitly hid behind a legal fiction. Victoria D.'s lawyer argued that equal protection required that Victoria ought to have an opportunity to rebut her presumed legitimacy because California law provided an exception that allowed her mother, and perhaps also the presumed father, to rebut the conclusive presumption of legitimacy. But, Scalia argued, "Illegitimacy is a legal construct, not a natural trait." Ibid., 4696. Enthusiastic deference to a "legal construct" then led Scalia to the extremely deferential "rational relationship" equal protection test and thereby to the rejection of Victoria's claim. 
The "Due Process" claim by the natural father and his daughter could not be upheld, Scalia explained, because the liberty they invoked lacked roots "in history and tradition". ${ }^{67}$ Indeed, to avoid the breakdown of the rule of law threatened by the dissenters' pluralistic approach, Scalia asserted, there must be a rule to determine the appropriate level of historical generality to use in identifying constitutional tradition. ${ }^{68}$ The tradition behind the conclusive presumption was fundamental, Scalia argued, because he could trace its ancient Common Law roots. By contrast, the claimed biological parent-child relationship lacked such a tradition.

Even if one were to accept Scalia's notion of history as determinative, however, his pinched perspective on what counts as history is inadequate. Minority groups are simply left out. Yet to look almost anywhere in the nation is to see the continuing effects of racial and ethnic mixtures, combinations, and recombinations of white masters and black slaves, for example, or the diverse family structures of Native Americans, Hawaiians, and Spanish-speaking peoples. But attention to the family histories of such subgroups would demolish Scalia's happy homogenization of family tradition. Perhaps because history of families in the United States overflows with jagged edges and recalcitrant chunks, Scalia replaced the complex conglomeration of the past with a dream, a recipe that could yield a frothy, entirely nondescript concoction once all the ingredients were folded smoothly into an imaginary master blender. ${ }^{69}$

67 Ibid., 4694. Scalia said, "The family unit accorded traditional respect in our society, which we have referred to as the 'unitary family,' is typified, of course, by the marital family, but also includes the household of unmarried parents and their children." Ibid., n. 3. He did not explain why this was his family limit, though in Moore v. City of East Cleveland, 431 U.S. 494, 504 (1977) (plurality opinion) Justice Powell said the "tradition of uncles, aunts, cousins, and especially grandparents sharing a household" had "roots equally venerable and equally deserving of constitutional recognition" as the traditions protecting the nuclear family. Instead Scalia resorted to the "slippery slope argument" and claimed that the logic of Brennan's dissenting position would lead to the conclusion that if Michael had begotten Victoria by rape, he might assert the same liberty interest in his relationship with her that he did here. 57 U.S.L.W., at 4694 n. 4.

68 Scalia claimed that judges should discover "the most specific level at which a relevant tradition protecting, or denying protection to, the asserted right can be identified." Ibid., 4695 n. 6. It is noteworthy that only Chief Justice Rehnquist agreed to accompany Scalia in this excursion seeking a rule as to the appropriate level of historical abstraction.

69 It was thus unnecessary to consider more complex, nuanced family narratives. For good introductions to the relevant historical work, see, e.g., H. Gutman, The Black Family in Slavery and Freedom, 1750-1925 (1976); G. Nash, Red, White, 
In sharp contrast, Brennan's vehement dissent argued for an ongoing, open-ended assessment of fundamental values. Rather than view the Constitution as "a stagnant, archaic, hidebound document steeped in the prejudices and superstitions of a time long past", Brennan asserted, the Court should recognize that "[w]e are not an assimilative, homogenous society, but a facilitative, pluralistic one, in which we must be willing to abide someone else's unfamiliar or even repellent practice because the same tolerant impulse protects our idiosyncracies."70 Yet Brennan too readily conceded the relevant history to Scalia. Brennan condemned Scalia for "exclusively historical analysis" and for seeking the "tradition" Scalia considered determinative by "poring through dusty volumes of American history".71 But the dissenters failed to make any affirmative alternative historical case. They attacked Scalia's reliance on mandarin texts, but they did not suggest that the past, viewed from the bottom up and not exclusively from the formal vantage point of law books and treatises, would tell a very different historical story about families. Actually, such history complements the arguments the dissenters made about the advent of reliable blood tests, and changes in societal values, and explodes Scalia's parochial definition of tradition.

Ironically, Brennan and Scalia were on the same side in Mississippi Band of Choctaw v. Holyfield ${ }^{72}$ in which the Court also rejected the claims of natural parents. Justice Brennan's majority opinion in this case had to stretch considerably to give exclusive jurisdiction to the Choctaw tribal court. Twin babies, whose formal state court adoption was challenged by the tribe, had been adopted more than three years earlier by non-tribal parents through regular court procedures. The children were born 200 miles away and had never lived on, nor even visited, the Choctaw reservation. Their biological parents, both members of the tribe, voluntarily surrendered the twins for adoption a few weeks after the twins' birth. The biological parents continued to appear in court alongside the adoptive parents to urge that the initial state

and Black: The Peoples of Early America (1974); M. Sahlins, Islands of History (1985).

$70 \quad 57$ U.S.L.W. at 4699.

71 Ibid., 4698.

7257 U.S.L.W. 4409 (3 April 1989). Justice Brennan wrote the majority opinion, which turned on the technical question of the meaning of "domicile" for jurisdictional purposes within the Indian Child Welfare Act of 1978, 92 Stat. 3069, 25 U.S.C. Secs. 1901-1963; Justice Stevens, joined by Chief Justice Rehnquist and Justice Kennedy, dissented. The Court did not consider any constitutional issues. 
court adoption not be upset. Nevertheless, Brennan's latitudinarian statutory interpretation held that the twins' domicile remained on the reservation with which they never had contact, despite their biological parents' consistent efforts to avoid such a connection. The Court also found that Congress had intended the tribal court to have exclusive jurisdiction, even if this meant reopening an adoption that had endured without problems for over three years. ${ }^{73}$

Viewed together as double defeats for biological parents these two decisions are somewhat surprising in themselves. Upon closer examination, however, they become difficult to reconcile with one another and impossible to reconcile with the Court's approach in other recent decisions to overlapping realities of family, tribe, and racial groupings. At first glance, the Court in both Michael $\mathrm{H}$. and Mississippi Choctaw simply decided to defer to the legislative judgments of California and Congress respectively. Closer attention to what the Court said as well as to what it did suggests more significance in both decisions. We find a majority of the Justices seeking to advance particular legal constructs of the family, even if this means ignoring biological reality and the undisputed wishes of biological parents. ${ }^{74}$ Yet elsewhere biology and the wishes of biological parents loom large in Supreme Court decisions that deal with family and tribal units. ${ }^{75}$

Justice Brennan acknowledged that this result might undermine the important relationships already formed by the twins with their adoptive parents, but asserted that the tribal court was simply being given jurisdiction, and that it might take such factors into account in making its ultimate decision about where the twins should wind up.

74 This has been true for a long time, of course, as the Mormon polygamy decisions in the nineteenth century make clear, culminating in Reynolds v. United States, 98 U.S. 145 (1878) (upholding federal law making bigamy a crime against freedom of religion claim). What is remarkable, however, is that with the notable exception of the Mormons, other groups with unusual family practices were treated with considerably more sympathy than the current Supreme Court's approach suggests. See C. Weisbrod, The Boundaries of Utopia (1980). Another way in which government traditionally and directly affected how American families were constituted was through laws forbidding miscegenation. These laws finally were invalidated on individual liberty and group equal protection grounds in Loving v. Virginia, 388 U.S. 1 (1967), but it is hard to see how a majority of the current Court could reach that result today, given its willingness to defer to states in Michael $H$. and its requirement of specific discriminatory intent in Croson and similar decisions. Laws against miscegenation, after all, treat different races with formal equality.

75 See, e.g., Lehr v. Robertson, 465 U.S. 248 (1983) (functional definition of paternity from context of father's acts); Wisconsin v. Yoder, 406 U.S. 205 (1972) (right of Amish parents not to send children to school after eighth grade); 
Less than two months before Mississippi Choctaw, for example, the Court held that Joshua DeShaney had no constitutional basis upon which to claim protection from the state. Joshua was four when his father's beatings culminated in such severe head injuries that Joshua will almost surely spend the rest of his life in an institution for the profoundly retarded. The Court conceded that the record showed that State authorities knew of Joshua's plight. But Chief Justice Rehnquist's majority opinion held, "While the State may have been aware of the dangers Joshua faced in the free world, it played no part in their creation, nor did it do anything to render him any more vulnerable to them."76

Rehnquist divided children neatly into only two worlds. Some children are in state custody; all others must rely on their own family nexus and state law, or perhaps the kindness of strangers, in "the free world". Because Joshua DeShaney was not actually in state custody, Wisconsin had no constitutional duty to protect him. As he sustained beating after beating from the time he was two years old, Joshua could rely only on the father who beat him, to whom a state court had given custody of Joshua after his parents' divorce. ${ }^{77}$ Though the record disclosed numerous contacts between Joshua and government doctors, social workers, and police, Rehnquist reasoned that to hold that the multitude of interventions by government officials obliged Wisconsin to protect Joshua would give insufficient attention to the rights of families and would unfairly transform the state into "the permanent guarantor of an individual's safety by having once offered him shelter."78 According to the DeShaney decision, a family with custody of a child is

Stanley v. Illlinois, 405 U.S. 645 (1972) (natural father's right to raise illegitimate children). But see Bowen v. Gilliard, 483 U.S. 589 (1987) (Congress could require family receiving $A F D C$ to include payments from noncustodial parents earmarked for individual children in calculating family income). Other courts, of course, have begun to wrestle with the breakdown of definitions of "natural" families in cases involving surrogate mothers and biogenetics more generally.

DeShaney v. Winnebago County Department of Social Services, 109 S.Ct. 998, 1006 (1989) (emphasis added).

77 For a description of the background, and a critique of the majority opinion, see Soifer, "Moral Ambition, Formalism, and the 'Free World' of DeShaney", 57 Geo. Wash. L. Rev. 1513 (1989).

$78109 S . C t$., at 1006 . Here, Rehnquist responded specifically to the fact that Wisconsin's Child Protection Team that was regularly involved with Joshua actually once had taken temporary legal custody of him. Compare Schall v. Martin, 467 U.S. 253, 265 (1984), in which then-Justice Rehnquist wrote for the Court that children are "always in some form of custody" so that "if parental control falters, the State must play its part as parens patriae." 
the only source of protection for that child as a matter of constitutional law, unless and until the state formally takes or reassigns custody.

\section{Destruction of the Tribe}

It should be obvious that the tribal jurisdiction extended in Mississippi Choctaw functions in a universe less susceptible to binary choices than the free world/custody dichotomy crucial to the Court's reasoning in DeShaney. Lest anyone think that the Court suddenly grows soft when a case involves Native American tribal rights, however, we should first consider a few contrasting decisions. Hodel $v$. Irving ${ }^{79}$ for example, is far more typical of the Court's current approach to tribal claims. In fact, Hodel v. Irving can hardly be distinguished from Mississippi Choctaw. Both cases involved recent congressional legislation passed to protect tribes and to aid individuals by emphasizing benefits Native Americans derive from their tribal contexts. The dramatically conflicting results in the two cases suggest an unpleasant truth about the relative priority of property and children in the Court's view.

The Hodel Court unanimously conceded that Congress had made a good faith effort to respond to a serious, intractable problem: the "extreme fractionation of Indian lands." ${ }^{00}$ The statute provided that fractionated land holdings not devised during the lifetime of their owners would escheat to the tribe. Moreover, the Court conceded that "consolidation of Indian lands in the Tribe benefits the members of the Tribe." ${ }^{11}$ But the obvious benefit to all tribe members was easily outweighed, in the view of the Justices, by the vital importance of the right of individual holders even of de minimis property claims "to pass on

481 U.S. 704 (1987). Justice O'Connor wrote the Court's lead opinion and there were no dissents. Justice Brennan, joined by Justices Marshall and Blackmun, concurred separately, as did Justice Scalia, joined by Chief Justice Rehnquist and Justice Powell, and Justice Stevens, joined by Justice White. The particular cause of these seriatim opinions among Justices who all concurred in the result was whether the decision to invalidate a congressional statute on the basis of minimal property claims undercut other recent precedents, primarily Andrus v. Allard, 444 U.S. 51 (1979) (upholding ban on sale of all artifacts containing eagle feathers, on theory that the value of the artifacts nevertheless was not entirely destroyed).

80481 U.S. at 704 . The decision invalidated the original version of the Indian Land Consolidation Act of 1983, Pub. L. 97-459, Title II, 96 Stat. 2519, as a taking without just compensation.

81 Ibid., 481 U.S. at 715. Indeed, Justice O'Connor described the policy of allotment as "disastrous for Indians" and noted that the problem of fractionation would continue to compound over time. 
property". ${ }^{82}$ All individuals must be treated alike. The tribal context and the admitted tribal benefit were obliterated by this abstract equality idea, particularly because something as important as property rights was at issue. It is a bitter paradox that the Court deemed such purported universality much less essential when it was the custody of children at stake. By contrast, in Mississippi Choctaw the majority was extremely solicitous of tribal jurisdiction and deferential to Congress.

As if to underscore the relative unimportance of children in comparison to property when tribal authority is at issue, a few months later the Court returned to the vital importance of individual property rights in Brendale v. Confederated Tribes and Bands of the Yakima Indian Nation. ${ }^{83}$ The Justices protected the property rights of individual nonmembers of the tribe at considerable cost to tribal sovereignty and to historical accuracy.

82 Ibid., 711. The statutory section at issue affected only fractional interests that represented 2 percent or less of the total acreage of a tract that had earned the owner less than $\$ 100$ the previous year. The Court also acknowledged the headaches involved in administering tracts subdivided into hundreds of interests, many of which generate only pennies a year in rent. Yet Justice O'Connor extolled the significance of inheritance as "part of the Anglo-American legal system since feudal times". The rights of tribes, and their members, were no match for longstanding - one might almost say "inherited" - individual rights; the Justice intervened actively to vindicate these individual property rights and refused to defer to the recent judgment of Congress. Yet the Court returned to a deferential stance toward the Federal Government in Lyng v. Northwest Indian Cemetery Protective Ass'n, 485 U.S. 439, 451 (1988). Again writing for the majority, Justice O'Connor conceded that permitting a road to be built across a sacred Indian site "could have devastating effects on traditional Indian religious practices". She insisted, however, that the Government remained free to choose how to use "what is, after all, its land". Ibid., 453 (emphasis in original). Moreover, "government simply could not operate if it were required to satisfy every citizen's religious needs and desires." Ibid.

8357 U.S.L.W. 4999 (1989). In this decision, and two consolidated cases, the Supreme Court split into three camps on the question of whether the Yakima Tribe had exclusive zoning jurisdiction over property within its reservation in the state of Washington. The decisive duo - Justice Stevens joined by Justice O'Connor - used their swing votes to determine that the tribe could continue to exercise control over a site in what had been the closed area of the reservation, at least when the owner sought to develop the land in a way that might harm the environment. But, they determined, the tribe had to cede authority to the local county zoning process in the case of a parcel held in fee on the more open part of the reservation. A second group - Justice White, joined by Chief Justice Rehnquist and Justices Scalia and Kennedy - would have deprived the tribe of zoning authority entirely. The third group - Justices Blackmun, Brennan, and Marshall - would have given the tribe exclusive authority over all the land at issue. For a powerful, detailed critique of Brendale, see J. Singer, "Sovereignty and Property" [on file with author]. 
What is most striking about the Brendale morass is that the crucial factor in Stevens's decisive opinion was his belief that it was unthinkable that individual property holders in fee might be subjected to zoning by a government body, i.e., the Yakima Tribe, which they might not be able to join. Analogous situations that are permitted, such as huge blocks of real estate owned by foreign nationals, for example, or unaccountable corporate power in a variety of contemporary contexts, did not trouble Stevens and O'Connor. In fact, Stevens's opinion underscored the continuing hold of Lockean notions of individual property on American constitutional law. It also echoed Croson's fears about minority political power. Had the Justices considered history, they would have had to deal with the uncontested fact of blatant treaty violation by the Federal Government, as well as Congress's explicit repudiation of the statute upon which the majority relied, the 1887 Dawes Act, in the Indian Reorganization Act of 1934. But judicial myopia about history when Native American rights conflict with the claims of individual fee holders is itself a tragic old story. ${ }^{84}$

\section{Construction of Racial, Ethnic, and National Groups}

Deciding who is a member of a family or a tribe is basic, yet such a question is never free of difficulty. Moreover, deference to tribal or family norms, at least as judges perceive such norms to be, may defeat principles as important as the elimination of gender discrimination. ${ }^{85}$ Judicial struggles to define membership in racial, ethnic, and national

84 For enlightening recent treatment of basic themes concerning the legal history of Indian tribes, see Williams, supra note $61 ; \mathrm{M}$. Ball, "Constitution, Court, Indian Tribes," 1987 Am. B. Found. Res. J. 1.

85 Santa Clara Pueblo v. Martinez, 436 U.S. 49 (1978) (no implied right of action in federal court to challenge alleged gender discrimination by tribe); AttorneyGeneral of Canada v. Lavell; Isaac v. Bedard, 38 D.L.R. (3d) 481 (1973) (upholding exclusion of Indian women who married non-members of tribe). But Canada's law allowing revocation of a woman's Indian status for marrying a nonIndian was said to violate the right to freedom of association, protected in Article 27 of the International Covenant on Civil and Political Rights. Matter of Lovelace v. Canada, Communication No. R/24 (31 July 1981), U.N. Doc. CCPR/c/DR(XIII) R, 6/24. For a useful discussion of international law in the context of sovereignty claims by North American Indians, see Note, "Toward Consent and Cooperation: Reconsidering the Political Status of Indian Nations", 22 Harv. C.R.-C.L.L. Rev. 597 (1987). For a devastating critique of the decision in Santa Clara Pueblo, including historical information on that tribe's much more complex treatment of gender, see J. Resnik, "Dependent Sovereigns: Indian Tribes, States, and the Federal Courts", 56 U. Chi. L. Rev. 671 (1989). 
groups further illuminate the dangers of purported neutrality when there are important legal consequences of group identity at stake.

In ironic contrast to the two Patterson opinions discussed above, for example, the United States Supreme Court decided in 1987 that the same 1866 Civil Rights Act at issue in Patterson might be invoked by Arabs and Jews to attack alleged discrimination against them. An antic sense of humour may have informed the Court's decision to consider Saint Francis College v. Al-Khazraji ${ }^{86}$ and Shaare Tefila Congregation v. $\mathrm{Cobb}^{87}$ together. Prior decisions had determined clearly that discrimination against whites was actionable under Sections 1981 and 1982 , but now the Court wrestled with the thorny issue of alleged discrimination based on the plaintiffs' Arab and Jewish identities respectively.

In Saint Francis College, an Arab professor alleged discrimination when a Catholic college denied him tenure. The issue, as the Court framed it, was: "[W]hether a person of Arabian ancestry was protected from racial discrimination under Sec. 1981." ${ }^{88}$ Justice White's answer for the unanimous Court was that it was unnecessary to determine the current racial characterization of Arabs. ${ }^{89}$ Instead, White held, "the understanding of 'race' in the 19 th century" ${ }^{90}$ should be decisive.

The Court sought that understanding primarily through a very brief survey of 19th century dictionaries and encyclopedias, supplemented by a smattering of the legislative history of Section 1981. Because the mid-19th century American sources the Court consulted generally defined "race" in terms of "stock", "lineage", and "ancestry", and because encyclopedias and Congressmen alike seemed to distinguish "Arabs, Englishmen, Germans and certain other ethnic groups" from one another as separate races, the Court claimed "little trouble" in

88481 U.S. at 607 . Section 1981 contains that remnant of the original 1866 Civil Rights Act dealing with contracts that was also at issue in Patterson. Though the Statute does not use the word "race", precedents such as Runyon v. McCrary, 427 U.S. $160(1976)$ have made it clear that racial discrimination is prohibited by Section 1981 in private as well as public contracts. The Court, in Saint Francis College, also dealt with a statute of limitations issue not relevant here.

In an important footnote, White criticized popular understanding that there are three major human races - Caucasoid, Mongoloid, and Negroid - from the perspective of modern biologists and anthropologists. He noted that some, but not all, scientists have concluded that "racial classifications are for the most part sociopolitical, rather than biological, in nature", and that "[c]lear-cut categories do not exist". 481 U.S., at 610 n. 4. Ibid., 610. 
concluding "that Congress intended to protect from discrimination identifiable classes of persons who are subjected to intentional discrimination solely because of their ancestry or ethnic characteristics". ${ }^{91}$ While White noted that distinctive physiognomy is not essential to qualify under Section 1981, he added that if Al-Khazraji had claimed discrimination based "solely on the place or nation of origin, or his religion", the statute would not have protected him. ${ }^{92}$

After anti-Semitic slogans were sprayed on the walls of a suburban synagogue, Jewish plaintiffs tried to claim that "Jews are not a racially distinct group" but that, nevertheless, they ought to be protected as Jews under Section 1982 because the perpetrators of the spray-painting "viewed Jews as racially distinct and were motivated by racial prejudice". ${ }^{93}$ The Court refused to thread so fine a needle. Nevertheless, the unanimous Court, mostly by reference to its treatment of $\mathrm{Al}$ Khazraji's case, held that when Section 1982 was adopted, "Jews and Arabs were among the peoples then considered to be distinct races and hence within the protection of the statute." $" 94$

The result, if perhaps not the reasoning, seems right in both these cases. The 1866 Civil Rights Act did seek to reach "at a minimum", as the Court of Appeals put it, "discrimination directed against an individual because he or she is genetically part of an ethnically and physiognomically distinctive sub-grouping of homo sapiens." 95 Yet the Court's reliance on selections from a few dictionaries and encyclopedias is glib, an example of the methodology of law office history. Moreover, even the few snippets from the Congressional debates illustrate the implausibility of the distinction White tried to draw between discrimination based on racial or ethnic characteristics, on the one face, and discrimination based on place or nation of origin, on the

92 Ibid., 613. The Court thus approved the Court of Appeals holding that being "genetically part of an ethnically and physiognomically distinctive subgrouping", quoted, ibid., would be sufficient, but held such a showing not necessary to establish a discrimination claim under the statute. Justice Brennan concurred separately and argued that any line separating ancestry and ethnic characteristics from place or nation of origin could hardly offer a bright line test. Ibid., 614 .

Shaare Tefila Congregation v. Cobb, 481 U.S. 615, 616 (1987). Justice White again wrote for the unanimous Court.

Ibid., 617-18.

Ibid., 607, quoting with approval $784 F .2 d 505,517$ (3rd Cir. 1986) \& ibid., at 607. For historical sources that support the important point that this statement describes only the bare minimum of the coverage of the 1866 Civil Rights Act, see supra, note 51 . 
other. ${ }^{96}$ The malleability of these categories is further underscored by their subsequent history. Nevertheless, there is obviously still weight in calling Jews a race, for example, and it is a variable weight that depends on the perspective of the identifier as well as those identified. ${ }^{97}$ To ignore the baggage of that history is both insular and woefully unrealistic.

\section{E. An English Coda}

It is a commonplace that people in the United States "are a people of the present, and have no heartfelt interest in the olden time". ${ }^{98}$ Perhaps it is not surprising to find that judges in the United States pay little attention to history. At first glance, it may be more surprising to find judges in England, a country that sometimes appears overladen with history, apparently similarly unaware of a checkered past. For example, Lord Denning, long Master of the Rolls and surely one of the most distinguished English judges of his era, revealed naivete about various

96 Thus, White relied on comments made by Representative Bingham when the 1866 Act was repassed in 1870 . Bingham claimed that the Act provided "that the States shall not hereafter discriminate against the immigrant from China and in favor of the immigrant from Prussia, nor against the immigrant from France and in favor of the immigrant from Ireland." Cong. Globe, 41st Cong., 2nd Sess., 3871 (1870). Precisely the examples White used by way of illustration - as well as many others he might have invoked, particularly a favourite reference of the time to discrimination against "Celtic Irishmen" - undercut the distinction White advanced in Saint Francis.

97 In summarizing recent studies of Southerners, for example, the distinguished historian C. Vann Woodward recently wrote, "Whites identify themselves with the South more than Catholics with their religion, more than union members with other unionists, and at about the same levels as blacks and Jews with other members of their race [sic]." N.Y. Rev. of Books (26 October 1989), at 16. A much-publicized historical example occurred in a colloquy between Senator Henry Cabot Lodge and Julian Mack before the United States Immigration Commission in 1909. Mack was appalled when Senator Lodge, citing Cyrus Adler, referred to "the Jewish race." Mack responded, "I do not recognize the Jewish race." Quoted in Ch. 13, "What Is a Jew?", in H. Barnard, The Forging of the American Jew: The Life and Times of Judge Julian W. Mack 93-100 (1974). Mack had a distinguished career as chief lieutenant to Louis D. Brandeis in the Zionist cause and as a federal judge; somewhat ironically, Mack headed the separate Committee of Jewish Delegates in Versailles in 1919. Like Brandeis, Mack had come to believe in hyphenated American Judaism. As Harold Laski observed in 1916, however, "Whether we will or no, we are bundles of hyphens. When the centers of linkage conflict a choice must be made." $H$. Laski, "The Personality of Associations", 29 Harv. L. Rev. 404, 425 (1916). sions of the Past: The Historical Imagination in American Fiction 92 (1974). 
group histories similar to that of his American counterparts, at least in cases about "involuntary associations".

Lord Denning's well-known opinion in Mandla v. Dowell Lee $e^{99}$ may be read as a counterpart to the American decisions just discussed. It further illustrates the importance of looking up from one's dictionary to contemplate the context of the past. This is not to suggest that the general legal question involved, nor the specific case before Lord Denning, made for an easy Dworkinian case. But sensitivity to group histories might avoid drawing particularly embarrassing analogies, as did Lord Denning.

The Mandla case arose when a Sikh solicitor tried to enroll his son in the Park Grove Private School. He was told by the headmaster that his son could not be enrolled unless the boy removed his turban and cut his hair, both acts forbidden by orthodox Sikh belief. ${ }^{100}$ The issue before the Court of Appeal was: "[W] hat is a 'racial group' within the Race Relations Act of 1976?"101 Because the Act clearly did not cover discrimination based on religion, politics or culture, Lord Denning reduced the issue to whether Sikhs ought to be considered a group "defined by reference to ethnic origins". He then took up the meaning of "ethnic" with a display of erudition about its Greek origin and its use in the translation of the Old Testament from Hebrew. He traced development of "ethnic" from meaning a "non-Israelitish" nation to "not Christian or Jewish" to the "entirely different meaning" noted in the 1934 Concise Oxford Dictionary. ${ }^{102}$ This was the meaning Lord Denning embraced because, he explained, "That is the meaning which

The headmaster's position was that he had not rejected the boy because he was a Sikh. There were already several Sikhs in the school, for one thing, and "[i]t was the turban that was rejected." [1982] 3 All E.R. at 1111 (quoting headmaster).

Ibid. The 1976 Act, Section 3 (1) defined "racial group" as "group of persons defined by reference to colour, race, nationality or ethnic or national origins". Lord Denning noted that everything turned on the issue of whether Sikhs are a racial group, since discrimination in education is prohibited under the Act whether it is direct or indirect. Lord Kerr found it a "difficult and troubling case." [1982] 3 All E.R. at 1118. He also engaged in etymological research and explained that the 1976 Act included protection from discrimination based on "nationality" after the House of Lords had decided that "national origins" was not to be equated with "nationality" in Ealing London Borough v. Race Relations Board, [1972] 1 All E.R. 105, [1972] A.C. 342. Lord Kerr determined, however, that Sikhs are "only distinctive because they adhere to distinct religious, political or social beliefs and customs," ibid., 1122, and are therefore not within the protection of the Act.

[1982] 3 All E.R. at 1111. 
I, acquiring my vocabulary in 1934 , have always attached to the word 'ethnic".'103

This sounded solipsistic. But Lord Denning went on to acknowledge that new meanings have been given to the term "ethnic" since 1934. In the second supplement of the Oxford English Dictionary, he found a reference to a source which, in turn, referred to "Jews" as the "bestknown example" of ethnic grouping. ${ }^{104}$ This led to a curious excursion. Lord Denning sought support for his notion that it is "a racial characteristic" that distinguishes Jews from non-Jews. He capped his analogy by saying: "There must be no discrimination against Jews in England. Anti-Semitism must not be allowed. It has produced great evils elsewhere. It must not be allowed here." "105 Unfortunately, the ahistorical implication of this otherwise noble declaration seems to be that antiSemitism had not been a problem in England's past. After all, Lord Denning asserted, "There is nothing in their culture or language or literature to mark out Jews in England from others. The Jews in England share all of these characteristics equally with the rest of us. Apart from religion, the one characteristic which is different is a racial characteristic."106 This awkward use of we/they belies the claim that

Ibid. This quite remarkable statement specifying the year in which he acquired his vocabulary not surprisingly led to the further statement that "It is, to my mind, the correct meaning." That correct meaning was "pertaining to race".

Ibid., 1112. Lord Denning was justly famous for his iconoclasm about legal precedent. Yet this formalistic hop from sourcebook to sourcebook is reminiscent of the scene in the Marx Brothers' movie, "Day at the Races", in which Groucho learns that every thick racing tout he buys from Chico only leads to another book - and Groucho winds up selling tootsie-fruitsie ice cream from Chico's cart.

Ibid., 1113.

106 Ibid., 1112. It may be that Lord Denning, always something of a judicial maverick, was becoming increasingly insensitive to claims by minorities while he continued as Master of the Rolls into his 80 s. Lord Denning finally resigned amidst controversy over allegedly racist statements in a book he had published. But there is considerable evidence that Lord Denning had been quite insensitive to claims by members of groups he considered different for a considerable time. For a balanced but critical view, see C. Palley, "Lord Denning and Human Rights - Reassertion of the Right to Justice," in Lord Denning: the Judge and the Law (J. L. Jowell \& J. P. W. B. McAuslan, eds., 1984). Moreover, Lord Denning's oft-repeated admiration for "the Christian religion, his native country, and the defence forces and police", R. F. V. Heuston, "Lord Denning: The Man and his Times", ibid., 19 (citations omitted) often left him apparently unaware of different perspectives. Lest it be thought I have concentrated on an unimportant viewpoint, however, Lord Scarman spoke for many when, in 1977, he declared that the legal history of the previous 25 years would never be forgotten as "the 
neither past history nor legal distinctions are still relevant. When Lord Denning turned to the Sikhs, he found them neither racially nor physically distinct from other Indian peoples, so it was plain to him that Sikhs are distinguished only by their religion and culture, categories not covered by the Act. ${ }^{107}$

On appeal, the House of Lords reversed. In particular, Lord Fraser of Tullybelton criticized Lord Denning not only for the result he reached but also for his view of the Commission and even for his Greek etymology. ${ }^{108}$ Lord Fraser argued that while dictionaries might be helpful, they were of greatest use in demonstrating that "ethnic has come to be commonly used in a sense appreciably wider than the strictly racial or biological". ${ }^{109}$ As had a New Zealand decision, Lord

age of legal aid, law reform - and Lord Denning", The Times, 5 January 1977, Special Report Supplement, quoted (perhaps immodestly) in Lord Denning, The Discipline of Law 315 (1979), as well as by many others.

107 Sikhs may be a distinct community, he noted, "But that is not good enough. It does not enable them to complain of discrimination against them." [1982] 3 All E.R. Ibid., 1114. After all, Lord Denning explained, "You must remember that it is perfectly lawful to discriminate against groups of people to whom you object, so long as they are not a racial group" such as permissible discrimination against "the Moonies or the skinheads". Though he claimed Sikhs are different, in that they are "a fine community upholding the highest standards", the principle permits discrimination against them as well. Lord Denning also took the opportunity in this, his last judgment before retiring, to scold the Commission for Racial Equality for interfering with the headmaster's difficult job. Concurring, Lord Oliver went even further in scolding the Commission for its use of machinery designed to protect the weak "as an engine of oppression" against the headmaster, ibid., 1118; Lord Kerr described the Commission's interview with the headmaster as "more like an inquisition than an interview" and as "harassment of the headmaster." Ibid., 1123.

108 [1983] 1 All E.R. 1062. Lords Edmund-Davies, Roskill, and Brandon of Oakbrook all briefly noted their agreement with Lord Fraser; Lord Templeman wrote at greater length to explain why, "in view of the history of this country since the 1939-45 war I find it impossible to believe that Parliament intended to exclude the Sikhs from the benefit of the Race Relations Act 1976." [1983] 1 All E.R. 1071. He concluded that Sikhs possess "some of the characteristics of a race, namely group descent, a group of geographical origin and a group history." Ibid., 1072.

Ibid., 1066. It is noteworthy that Lord Fraser's useful list of criteria to define an ethnic group began with "a long shared history, of which the group is conscious as distinguishing it from other groups, and the memory of which it keeps alive", and added "a cultural tradition of its own, including family and social customs and manners, often but not necessarily associated with religious observance" as the other essential criterion. Lord Fraser provided five additional relevant, but not essential, criteria. Ibid., 1067. 
Fraser emphasized history, specifically a group's "particular historical identity" and its members' "belief as to their historical antecedents". ${ }^{110}$ He said it ought to make no difference whether someone entered such a group by birth or by adherence. Moreover, Lord Fraser read the Act to reject both the headmaster's justifications of his school uniform rule and his argument that, because a Sikh physically could comply with the regulation, it ought not be considered discriminatory. ${ }^{111}$ For all his open-mindedness, however, Lord Fraser relied on a curious nonsequitur to explain Parliament's intention. He argued, "[ $[1]$ is inconceivable that Parliament would have legislated against racial discrimination intending that the protection should not apply either to Christians or (above all) to Jews." This argument blatantly proves too much: either discrimination on religious grounds must be covered, although all conceded that religious discrimination was not prohibited by the statute, or Christians and Jews are (analogous) ethnic or racial groups. The tangled history of English anti-Semitism and of conflicted AngloJewish identity threatens Lord Fraser's fine effort to consider both the objective and subjective aspects of the history of the Sikhs. ${ }^{12}$

110 Ibid., 1068, quoting King-Ansell v. Police, [1979] 2 N.Z.L.R. 531, 542-43 (Richardson J.) (holding that Jews constituted a group protected under Section 25 of the New Zealand Race Relations Act of 1971, which forbade group incitement on the ground of "colour, race, or ethnic or national origins").

111 Lord Fraser expressed "much sympathy" with the headmaster's principal justificatory argument that he "sought to run a Christian school", but still found this claim impossible to sustain because it would be inconsistent with the Act's prohibition of discrimination based on ethnic origin. Ibid., 1070. Lord Fraser also explained that while a Sikh obviously was physically able to remove his turban, and thus might come within the Act's "can comply" baseline for determining that there was no discrimination, he read "can comply" not literally but rather to mean "can consistently with the customs and cultural conditions of the ... group", ibid., 1069, citing Price v. Civil Service Commission, [1978] 1 All E.R. 1228, [1977] 1 W.L.R. 1417.

112 Two separate difficulties stand out. First, as Lord Simon of Glaisdale noted in London Borough of Ealing v. Race Relations Board, [1972] 1 All E.R. 105, 114-15, "There have been periods in our history which have been disgraced by acute xenophobia" (examples omitted); now Parliament had responded with "rubbery and elusive language - understandably when the draftsman is dealing with so unprecise a concept as 'race' in its popular sense and endeavouring to leave no loophole for evasion." (It is worth noting that Lord Simon joined in holding that "national origins" in the 1968 Race Relations Act did not include discrimination based on "nationality", and Parliament responded by including both categories in the 1976 Race Relations Act.) It is unlikely that, in the face of the omission of religious discrimination from the statute's coverage, Parliament intended to prohibit all discrimination against Jews or, for that matter, against 
Nevertheless, Lord Fraser's opinion contrasts quite starkly with the narrow perceptions of his judicial counterparts in the United States. It is probably not discreet to mention other English decisions, old and new, that seem closer to the insularity of the American judges, but several important examples are worthy of note here. ${ }^{113}$ Moreover, any consideration of judicial responses to group claims in the context of Northern Ireland darkens the picture considerably. With such notable exceptions, however, the famously insular English judges seem a bit more attuned today to the historic bases of ethnic and racial group claims than do their contemporaries on the United States Supreme Court, though considerably less so when religious claims are raised.

In recent years, the United States Supreme Court has pushed free exercise of religion claims in seemingly opposite directions. The Court is unsympathetic to attacks on conditions imposed for government benefits that conflict with the religious beliefs of members of discrete and insular groups. ${ }^{114}$ Yet the Court emphasized that Illinois violated

some Christians by other Christians or by other groups. Second, Lord Fraser seemed simply to assume that English Jews wish to be considered separate, in ways akin to separate racial or ethnic classifications. But there is a long tradition to the contrary.

113 A recent constitutional law book put the matter succinctly: "Only in exceptional circumstances did the common law provide protection for members of minority groups." E.L.S. Wade \& A.W. Bradley, Constitutional and Administrative Law 574 (10th ed., 1985). And Parliament was hardly more tolerant. See generally C. Roth, A History of the Jews in England (3rd ed., 1964). After Cromwell allowed the Jews legally to return to England, for example, Jews continued to be legally excluded from all public life and all universities for two centuries. Moreover, anti-Semitism may be simultaneously rampant and genteel. Cf. H. Laski, "Notes on the Strict Interpretation of Ecclesiastical Trusts," 36 Canadian L. Times 190, 193 (1916) (cy pres applying trust for support of Jewish yeshiva to support of Anglican school). Even some recent decisions suggest limited toleration of distinctly different groups, see e.g., R. v. Lemon, [1979] A.C. 617 (upholding conviction of editor and publisher of Gay News for blasphemous libel when they "vilify Christ in His life and crucifixion" - disagreement only over holding that specific intent need not be proved and argument by Lord Scarman that blasphemy "is not sufficiently comprehensive" and ought no longer to be "shackled by the chains of history" to protect only Christian religion. (This decision was upheld by the European Commission on Human Rights, Gay News Ltd. v. United Kingdom, 5 Eur. Comm. H.R. 123 (1982)); Ostreicher v. Secretary of State for the Environment, [1979] $37 P . \& C . R .9$ (C.A.) (refusing to quash compulsory purchase order though hearing held on Jewish holiday when applicant alleged she could neither work nor hire another to work for her); Ahmad v. Inner London Education Authority, [1977] 3 W.L.R. 396 (Muslim not allowed to make arrangements for time off from teaching duties for religious worship). 
an individual's Free Exercise right when it denied him unemployment compensation "regardless of whether the individual's refusal to work on Sunday is in response to the command of a particular religious sect". ${ }^{115}$ Sincere religious belief by an individual was the only touchstone, according to the unanimous Court. The trend toward uniformity, which includes rejection of free exercise claims rooted in longstanding religious group beliefs, contrasts sharply with respect for an entirely individualistic religious claim in Frazee. Together, these decisions suggest another way in which the contemporary American legal climate is losing sympathy with group identification. In the modern welfare state, in which government programmes serve as invaluable sources of both wealth and status, purportedly neutral policies that actually impinge on the group identifications of distinct and insular minority groups deserve special judicial scrutiny.

\section{F. "To Know. . What We See"}

During the early days of the Gilded Age, Justice Stephen Field had to decide whether it was constitutional for San Francisco's sheriff to cut the hair of all prisoners within an inch of their scalps. This equal haircut rule was not challenged by crypto-Hippies, but by Chinese prisoners. If Field generally embraced formal judicial principles and free competition with an enthusiasm (and inconsistency) similar to that of current Justices, he nevertheless invalidated the rule, stating: "When we take our seats on the bench we are not struck with blindness, and forbidden to know as judges what we see as men." 116

American father's claim that to be required to furnish a social security number for his daughter, Little Bird of the Snow, as a condition for receiving federal aid and food stamps conflicted with his family's religious beliefs. See also Employment Division, Oregon Dept. of Human Resources v. Smith, 58 U.S.L.W. 4433 (17 April 1990) (proclaiming new, strong presumption in favour of laws of general applicability even if they seriously interfere with basic religious practices, such as ritual use of peyote by members of the Native American Church). $C f$. Lyng v. Northwest Indian Cemetery Protective Ass'n, supra note 82; Goldman v. Weinberger, 475 U.S. 503 (1986) (Orthodox Jew could be forbidden to wear yarmulke during military service).

Frazee v. Illinois Dept. of Employment Security, 57 U.S.L.W. 4397 (1989). Justice White wrote the brief, unanimous opinion.

116 Ho Ah Kow v. Nunan, 12 Fed. Cas. 252, 255 (No. 6,546) (C.C.D. Cal. 1879). For Field's views generally, see C. Swisher, Stephen J. Field: Craftsman of the Law (1930); C. McCurdy, "Justice Field and the Jurisprudence of GovernmentBusiness Relations: Some Parameters of Laissez-Faire Constitutionalism, 18631897", 61 J. Am. Hist. 970 (1975). 
Consideration of "a fact in its history" 117 convinced Field that San Francisco had targeted Chinese prisoners. Sheriff Nunan cut off the queues that the Chinese considered sacred. Field held this "altogether disproportionate" suffering unconstitutional. ${ }^{118}$ Justice Field thus was a pioneer in recognizing prisoners' rights, but his opinion is important beyond the anti-Chinese motives he perceived behind the neutral mask of equality. ${ }^{119}$ It illustrates why there must be judicial willingness to grasp "a fact in its history" in dealing with minority groups. That sensitivity includes cognizance of discrimination in the guise of evenhandedness as well as more overt bigotry.

Yet, in contrast, the modern tales we considered are full of selfsatisfied legal abstractions. They lack specifics about diverse people and traditions that give rise to group exceptionalism. These contemporary judicial narratives reflect and produce Whiggish law. Any complexity, and certainly any bleakness, that might contradict the happy endings the judges conclusively presume would be upsetting. To consider that past wrongs may be visited upon current group members would sap teleological faith in the neutral, even-handed principles of

11712 Fed. Cas., at 255. Justice Field's realistic approach was echoed directly in Justice Harlan's famous dissent in Plessy v. Ferguson, 163 U.S. 537 (1896). Harlan attacked the idea that separate railroad facilities might be equal, because "Every one knows" that the Statute's primary purpose was discrimination, thereby violating the principle that "Our Constitution is color-blind." Ibid., 557, 559. That realistic perception by judges is often problematic, however, is suggested by Harlan's assertions elsewhere in this dissent that the white race was and would remain superior in fact. Moreover, in Plessy, an aged Justice Field joined in Justice Brown's infamous majority opinion.

$11812 \mathrm{Fed}$. Cas., at 256-57. Justice Field, sitting as a single Justice, actually based his decision on the Eighth Amendment's prohibition against "cruel and unusual punishment", without indicating any concern about how it might apply to state, rather than federal, action. To illustrate further how laws "general in their terms, would operate only upon a special class, or upon a class, with exceptional severity", and thus would be unconstitutional, Field mentioned "the large number of Jews" in San Francisco, "a highly intellectual race ... generally obedient to the laws of the country." Ibid., 255. He suggested that should there be Jewish prisoners, their "peculiar opinions with respect to the use of certain articles of food" would make it unconstitutional to impose the same prison diet of pork upon them as might be imposed on everyone else.

119 The Court's most famous statement about unconstitutional discriminatory motive occurred a few years later in another case of the discriminatory application of law to Chinese aliens in San Francisco, Yick Wo v. Hopkins, 118 U.S. 356, 373-74 (1886) (if law "fair on its face and impartial in appearance ... is applied and administered by public authority with an evil eye and an unequal hand", it is unconstitutional). 
the current legal system. Therefore, contemporary judges must squelch particularized historical arguments. This may be crucial because, as William Wiecek put it, "oppressed peoples have an acute sense of their past ... they must: it is the crucible of their identity and their cohesion. Without it their present oppression becomes either meaningless or natural." 120

\section{CONCLUSION}

Tragic history cannot be trump in every legal contest. But the quest for a single level on which everyone is similarly situated sacrifices the diverse history of groups for abstractions about deracinated individuals who float equally above reality. Yet we have not reached once upon a time. Even when judges declare it, they cannot so easily purge the past.

The traditions and historical sense of different groups are part of "the factual surround of legal arrangements". ${ }^{121}$ Footnote four's suggestion of special scrutiny for claims of discrete and insular minorities never flourished fully. Today, however, we lose sight of the clashing norms that are anchored in groups. Sentimental haze obscures history. Judges pave over the shards of the past. As they do so, these judges proclaim that they are merely doing a bit of groundskeeping on a lovely, smooth, and level playing field open to all.

Despite a few success stories, group differences still count. ${ }^{122}$ Yet in Patterson, Croson, and Hodel v. Irving, for example, the Court intervened to invalidate efforts by popularly-elected bodies to remedy past wrongs perpetrated against paradigmatic discrete and insular minorities. Moreover, judicial struggles to define membership in families and tribes, and in racial or ethnic groups, underscore how aggressive judges

120 W. Wiecek, "Preface: The Historical Race Relations Symposium", 17 Rutgers L. J. 407, 412 (1986). Or as Renan noted a century ago, "[P]eoplehood is cemented by shared memories of common suffering", quoted in Dinstein, "Collective Human Rights", supra note 3, at 104. For a forceful elaboration in the context of descendants of slaves in the United States, see P. Williams, "Alchemical Notes: Reconstructing Ideals from Deconstructed Rights”, 22 Harv. C.R.-C.L.L. Rev. 401 (1987).

121 M. Galanter, "Review Essay: Outside, Inside: Jewish Justices in the Homeless Society", 14 Law \& Social Inquiry 507, 522 (1989) (discussing C. Wright Mills's sense of "sociological imagination").

122 Minow, supra note 58; W. G. Sumner, Folkways 12-13 (1906). The decisions discussed above may demonstrate that "it is a happy faculty of the mind to slough that which conscience refuses to assimilate". W. Faulkner, Light in August 376 (1932, paper ed. 1987). 
have become in constructing the problematic group categories they prefer to consider natural, almost Platonic, essences.

The decisions we considered are particularly dismaying because judges actually may be able to help legitimate ideals not otherwise widely accepted. ${ }^{123}$ Instead, the Anglo-American judicial treatment of involuntary groups today seems to have little doubt about a unified, homogenized past. ${ }^{124}$ Neutral rules crisscross with presumed equality. There is no iron, only velvet, as pleasant abstractions beyond history stretch back to a golden time immemorial.

It is important, as Yoram Dinstein has suggested, that when we deal with human rights, that we make the effort "to climb down to earth". ${ }^{125}$ If particularism is to be the foundation for Jacob's Ladder, however, an entirely ad hoc approach might bury us in lawless waves of sand. ${ }^{126}$ Legal actors must consider similarities and differences between group experiences if we are to produce thoughtful decisions in cases that arise from particular contexts. Therefore, a few normative suggestions for judicial treatment of minority rights may be in order:

(1) Judges must scrupulously scrutinize both public and private actions or omissions that directly harm or stigmatize members of groups traditionally victimized. Legitimacy ought not to be presumed in actions - or even failure to act - that are directed at members of those involuntary groups who have been scapegoated repeatedly in the past.

(2) Proof of biased motivation for acts against members of such

For the most recent study and collection of empirical work on the ability of courts in the United States to elicit acceptance of public policies unpopular with the mass public, see Gibson, "Understandings of Justice: Institutional Legitimacy, Procedural Justice, and Political Tolerance", 23 Law \& Soc. Rev. 469 (1989).

In contrast to the ahistoricism we have considered, immediately after the Civil War, the United States Supreme Court insisted, "[W]e cannot shut our eyes to the public history." Sparrow v. Strong, 70 U.S. (3 Wall) 97, 104 (1866). Chief Justice Chase hardly seemed concerned about neutrality when his opinion for a unanimous Court argued that judicial notice of public history was particularly appropriate because the future of "vast mining interests ... contributing largely to the prosperity and improvement of the whole country," ibid., turned on the question.

125 This was part of Dinstein's explanation for initiating publication of the Israel Yearbook on Human Rights, 1 Israel Yearbook on Human Rights 14 (1971). Such realism seems particularly appropriate for academic critics tottering in easy chairs as we watch the fray.

126 "He who clings to a law does not fear the judgment that reinstates him in an order he believes in. But the keenest of human torments is to be judged without a law. Yet we are in that torment." A. Camus, The Fall 117 (J. O'Brien trans., 1957). 
groups must be sufficient, but not necessary, to allege discrimination. For example, Section 1 of the 1866 Civil Rights Act $^{127}$ includes a group mens rea concept. It does not require explicit proof of a discriminatory motive in a denial of equality, but it allows judges or juries to infer discriminatory motive in the way that Anglo-American law generally allows such inferences to be drawn. This approach is consistent with the statute's history; it also parallels the trend toward a focus on group liability in other legal areas. ${ }^{128}$

(3) At times, judges may have to seek evidence on "subjective" ideas about the identity of a particular involuntary group, including who is in and who is out of the group. Discerning group wishes is always difficult. Yet to ignore a collectivity's perceptions - and the question of whether an individual is, or perceives herself to be, part of the collectivity - is to hide behind the false universalism of conclusive presumptions. ${ }^{129}$ Group history may play a crucial role in such an inquiry.

None of these approaches seems likely to gain wide judicial acceptance any time soon. Myriad minority groups undoubtedly will survive and even thrive no matter what judges say. Group identities free and fetter what we are and what we can become. Perceptions of diverse histories will help sustain these groups as they struggle to overcome inertia, legal precedents, or worse. Nevertheless, consideration of history and context is crucial for judges, too. Such awareness transcends abstract theory. The nitty-gritty, earthbound quest to "do equal right" requires it. Complex, dark, even harrowing histories of discrete groups remain. They remind us that "The key to redemption is remembrance." 130

127 Discussed above in the context of the two Patterson decisions and the decisions in Saint Francis College and Shaare Tefilla Synagogue, supra text at notes 4251, 86-96.

128 This trend is evident in disparate legal realms such as criminal law, torts, and even the First Amendment. See, e.g. B. Fisse, "Reconstructing Corporate Criminal Law: Deterrence, Retribution, Fault, and Sanctions”, 56 S. Cal. L. Rev. 1141 (1983); R. L. Rabin, "The Historical Development of the Fault Principle: A Reinterpretation", 15 Ga. L. Rev. 925 (1981); Board of Education, Island Trees v. Pico, 457 U.S. 853 (1982) (plurality opinion focus on group's motivation for removal of books from public school library).

129 See, e.g., M. Minow, supra, note 58; J. Clifford, The Predicament of Culture (1988); J.G. Getman, "Voices," and M.G. Yudof, “Tea at the Palaz of Hoon': The Human Voice in Legal Rules," 66 Tex. L. Rev. 577, 589 (1988); D. A. Bell, "Serving Two Masters: Integration Ideals and Client Interests in School Desegregation Litigation", 85 Yale L. J. 470 (1976).

130 This statement by the Ba'al Shem Tov is used as the motto of Yad Vashem, the Holocaust memorial in Jerusalem. 